\title{
THE IMPACT OF ELECTRONIC COMMERCE ON THE DEVELOPMENT OF THE ACCOUNTING INFORMATION SYSTEM
}

\author{
Mohammed Salman OMAR* \\ ORCID ID: 0000-0002-0950-8439
}

\begin{abstract}
This study aims to identify the role of e-commerce in improving and developing the quality of the accounting information system by designing a questionnaire In this context, a questionnaire was prepared and 300 accountants who work for a group of commercial companies in the governorates of Duhok, Erbil, and Sulaymaniyah participate in this questionnaire. The number of received and correct questionnaires reached The number of received and correct questionnaires reached 280, which corresponds to $93 \%$ of the sample size studied. The Statistical Program for Social Sciences (SPSS) was used to analyze the study data. The study reached several results, but the most important ones are the increase in the efficiency of accounting information systems and in the ability to get the targets by relying on e-commerce. As the efficiency of accounting information systems has been increased, and the quality of its outputs has been raised. So, decision-makers have been able to adopt accounting information and trust it. The study puts forward some suggestions, most notably: the speed of obtaining data and communicating the resulting information to the beneficiaries, making use of the services arising from the spread of e-commerce, and the search for advanced services that can be provided in a manner that ensures these systems continue to maintain their effectiveness and increase their efficiency.
\end{abstract}

Keywords: Electronic Commerce, Electronic Accounting System, Information System.

\footnotetext{
* Sakarya Üniversitesi, İşletme Enstitüsü, Muhasebe ve Finansman Bölümü Yüksek Lisans Öğrencisi, mohammedbarware590@gmail.com
}

DOI: https://doi.org/10.53662/esamdergisi.937701 


\section{ELEKTRONIK TICARETIN MUHASEBE BİLGİ SİSTEMININ GELISŞiMINE ETKİSi}

Öz: Bu çalışma, e-ticaretin muhasebe bilgi sisteminin kalitesini iyileştirme ve geliştirmedeki rolünü belirlemeyi ve bir grup ticari şirkette çalışan muhasebecilere dağıtılan bir anket tasarlamaktadır. Duhok, Erbil ve Süleymaniye valiliklerinde (300) anket dağıtıldı. Alınan ve doğru anketlerin sayısı 280'e ulaşmıştır, bu da çalışılan örneklem büyüklüğünün\% 93'üne tekabül etmektedir. Çalışma verilerini analiz etmek için Sosyal Bilimler İstatistik Programı (SPSS) kullanıldı ve çalışma bir dizi sonuca ulaştı, bunlardan en önemlileri: Muhasebe bilgi sistemlerinin etkinliğindeki artış ve eticarete güvenerek hedeflere ulaşma yeteneğinin artmasıdır. Muhasebe bilgi sistemlerinin etkinliği arttıkça çıktılarının kalitesi de yükselmiştir. Böylece karar vericiler muhasebe bilgilerini benimseyebilmiş ve ona güvenebilmişlerdir. Çalışmanın en önemli kısmı, veri elde etme ve elde edilen bilgilerin yararlanıcılara iletilme hızı, eticaretin yaygınlaşmasından kaynaklanan hizmetlerden yararlanma ve bir şekilde sağlanabilecek gelişmiş hizmetlerin araştırılması gibi bazı öneriler sunmaktır. Bu, sistemin etkinliğini korumaya devam etmesi ve verimliliklerini artırmasını sağlaması açısından önemlidir.

Anahtar Kelimeler: Elektronik Ticaret, Elektronik Muhasebe Sistemi, Bilgi Sistemi.

\section{INTRODUCTION}

The rapid development that humanity has known in the field of informatics has introduced new ideas and perspectives on information, as it has become necessary to pay attention to it at the present time, and due to the rapid and radical changes witnessed by the accounting that the international accounting bodies have contributed to the development of new standards, and the process of data management, preparation, and delivery of reports. Because of its more complex and diversified users, this development has become an obligation for the accountant to be aware of the latest developments in accounting information systems and the interrelationships between them and other systems. The role of the traditional accountant has evolved to include the fields of information processing, their use, the design of information systems, and information technology. All this is because the accounting information system is a source of information that all administrative levels and external users need to rely on to make their decisions. 
As the electronic commercial contract is witnessing an increasing growth as it has become a huge proportion of the volume of international trade, owing to the tremendous technological development and the reason for this is due to the ease of concluding this contract. Still, the matter is more than that, as we find that global trade is increasingly dealing with any new customer who does not use the contracting method Electronic or electronic exchange so that there are many methods of contracting via the Internet, the most important of which are contracting via e-mail (web), and the most widespread contract is through a network of Web sites (e-mail) and contracting through conversation and argument. The science of technology has reached a new type of organization that does not have a specific location or administrative structure and even intangible Instead, its existence depends on the network and electronic exchange of data. This had a direct impact on accounting information systems in terms of their design and operating procedures.

Our research seeks to achieve a set of goals, such as identifying the problems and obstacles facing the development of accounting information systems in light of ecommerce. and strengthening the fundamentals and nature of the accounting system. and linking it to the nature of e-commerce. And access to an easy model in the use and implementation of electronic commerce helps in developing accounting information systems.

\section{MOTIVATION}

In recent years, the work of companies has expanded, large industrial companies and laboratories have appeared, and accounting operations have also increased, and that the accounting information system was manual, cumbersome, and very expensive. It was not able to give accurate information on time, even after the emergence of electronic commerce and the accounting information system. There is consensus among academics that the contribution of electronic commerce to raising the efficiency and effectiveness of accounting information systems and that relying on electronic commerce satisfies the users of the financial statements more than not relying on them because the use of this system has many advantages, such as the distribution of powers to the employees of the company's employees and this positively affects the reliability of the information and financial statements of the company, it means the presence of an internal control system in the information system.

\section{ACCOUNTING INFORMATION SYSTEM}

The accounting information system is defined as a specialized partial system of the management information system that aims to collect, operate and report information related to the financial operations of the institution, for example, sales operations are recorded in the organization's records, then the process is migrated to the assistant professor's accounts and then that process is summarized with other similar operations 
Presented in the balances of Mai Al-Mezan Auditing as one of the reports issued by the system. ${ }^{1}$

For any facility to achieve its goals, there must be a set of integrated systems so that every other system is completed. Among these systems is the accounting system that some consider the backbone of those systems, given that it links them all together and summarizes their results. So it consists of the following components:

Figure (1): the components of the accounting information system

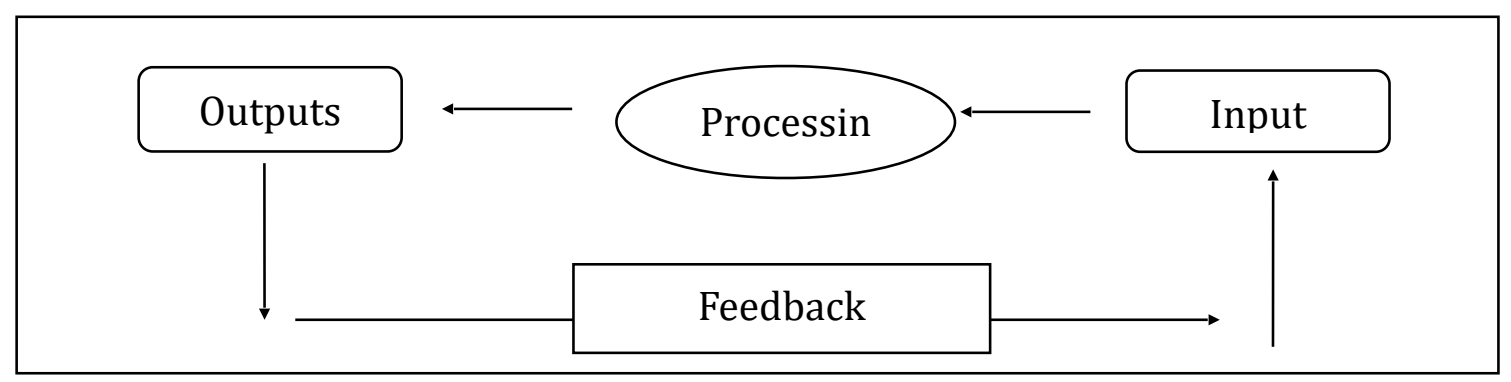

Source: Prepared by the researcher, depending on the sources

\section{TYPES OF ACCOUNTING SYSTEMS}

\section{First: The accounting system is manual:}

It is the system in which the inputs are processed, and the system is operated in order to produce the outputs manually. In other words, it is the system according to which its inputs are recorded, classified, and analysed in order to produce financial reports and summaries by manual work. ${ }^{2}$

\section{Second: The electronic accounting system:}

The technological development and the information revolution that the world is witnessing, and the great commercial and economic openness in the world in general and in Iraq in particular, necessitated the establishments to keep pace with these recent developments in the field of accounting information systems. ${ }^{3}$ The accountant must be familiar with the operational characteristics of computer systems in order to be able to

\footnotetext{
1 Shoaib Shouthari, The Effect of the Accounting Information System in Improving the Quality of Accounting Information(Algeria: Messila University, Institute of Administrative, Master Thesis, 2018),57.

2 Shfiya Bograra, The Importance of The Accounting Information System In Making strategic decisions (Duhok: Jihan University, Institute of Administrative, master thesis, 2020), 20-23.

${ }^{3}$ Faisal Kaiikh, The Effect of Using Electronic Accounting Information Systems on Improving Employee Performance (Tripoli: Kaja University, Institute of Adminstration, Master Thesis, 2021), 5-7.
} 
ensure the integrity of the accounting system and verify the correctness of the outputs. The digital electronic computer is a device that has been fed with a set of data and information on how to process this data in order to reach the targeted results. ${ }^{4}$

\section{E-COMMERCE}

In light of globalization and technological developments in various sectors and activities, especially commercial activity, which has gone through many and long stages affected by modern technology, which led to the birth of a new trade known as ecommerce, which is a modern type of exchange, where goods and services are sold, contracts, deals, and other commercial exchanges are concluded remotely, meaning without the presence of any of the parties to the exchange or contract, using the electronic communication technology represented by the Internet, which is a global network used by people and companies from all over the world without discrimination between them. ${ }^{5}$ It is a modern way of trade through the use of the Internet as a means of media to market products and services. Suppose the use of electronic commerce applications began in the 1970s then in the twenty-first century. In that case, the rapid spread of electronic commerce over the Internet, dealing with banks automatically, buying and selling via the Internet, and various services trade through it. ${ }^{6}$ The Organization of International Economic Cooperation and Development "is generally represented in the commercial transactions that take place by individuals and bodies that depend on the processing and transmission of digital data, voice, and image through open networks such as the Internet or closed that can be connected to the open network." E-commerce generally means exchanges of goods and services between at least two parties, whether one or both of them is an individual or the establishment, and whether the establishment is a company of people or funds, the important thing is that it is an organizational entity that practices business. It is necessary to complete this exchange and rely on one or more means to complete it, and accordingly the exchange process can be classified. ${ }^{7}$

\footnotetext{
${ }^{4}$ Abdul Razzaq Muhammad Qasim, Analysis and Design of Accounting Information Systems (Amman: Dar Al Thaqafa, 2009), 5-9.

5 Ikram Das, The Legal System for E-commerce Contracts (Szaq: Mohamed-Cherif Messaadia University, Facility of law, Master Thesis, 2020), 2-3.

${ }^{6}$ Hajjaj Yusef, E-Marketing Skills and Arts (Hebron: Dar Al-Walid, 2010), 7-9.

7 Nasser Khalil, Electronic Commerce (Amman: Osama House for Publishing, 2009), 49.
} 


\section{THE IMPACT OF ELECTRONIC COMMERCE ON ACCOUNTING INFORMATION SYSTEMS}

The use of the computers in accounting field has resulted in a change in most of the elements of the accounting system, as follows: ${ }^{8}$

a. Documents and the documentary cycle: The documents took the form of cards in particular sizes and shapes to facilitate data entry into the computer. There has also been a change in the documentary cycle, as most of the documents are used for registration in journals and ledgers.

b. Books and Records: Most of the books and records were dispensed with and became inside the computer in the form of files. The methods of storing data and information also changed. The use of electronic computers requires that all the pages of these books and records should be in the form of files inside the computer.

Lists and reports: The reliance on the electronic operation of the data led to the accuracy and speed in obtaining various reports over time.

\section{THE EFFECT OF USING COMPUTERS ON ACCOUNTING PROCEDURES}

The use of electronic computers in the field of accounting organization has resulted in a significant impact on the nature of accounting operations. These effects include the following:

First: Collecting, organizing, and analysing data:

Second: Centralization of document preservation after entry instead of being scattered in every section of the facility.

Third: Recording data in the journals and transferring it to the accounts in the ledger is done in one process. This saves time and reduces the chance of error as well as leads to shortening some stages in the accounting operations cycle. ${ }^{9}$

Fourth: The expansion of the scope of data analysis. After the analysis was done on a small scale and using traditional methods, after the use of electronic

\footnotetext{
${ }^{8}$ Abdul Zahid Al Samarrai- Samir Al Abdali, The Department of Sales and Electronic Sales (Amman: Ithraa House for Publishing, 2011), 13-14.

9 Muhammad Abd Hussain Al Faraj, Accounting Information Systems (Amman: Wael Publishing House, 2009), 19.
} 
computers, the analysis can be carried out on a large scale and in a scientific way and using the methods of operations research.

Fifth: a noticeable change in the method of presenting results and information, as computer outputs are used as reports, especially after developing the output unit and providing it with units for preparing graphs and inking. ${ }^{10}$

\section{THE EFFECT OF USING ELECTRONIC COMPUTERS ON THE CONCEPTS AND METHODS OF ACCOUNTING}

The use of electronic computers in the field of accounting had an essential role in developing their methods, as they used modern methods, including the following:

a. The electronic operation method has helped analyse, preserve, and retrieve data and information because manual methods have not become appropriate in the case of a large business volume.

b. Mathematical, statistical, and engineering methods in the field of data analysis, would not have been possible without the use of a computer.

c. Systems theory methods in designing accounting systems, studying their behaviour over time, and designing financial and administrative policies.

d. The scope of accounting and the development of its objectives has also expanded to include providing data and probabilistic information about the problem under different circumstances and under alternative policies with the required accuracy and time, using simulation methods and probabilities. ${ }^{11}$

\section{LITERATURE REVIEW}

The past two decades have witnessed a lot of studies and research in the field of e-commerce and its relation to accounting information systems, some of which are the following, some of which are consistent with our current research:

Fatima Ajmal, Norizan Mohd Yasin (2012) This study aimed to build a model for adopting e-commerce in small and medium enterprises, through which the most significant factors affecting the adoption process were identified. These factors were

\footnotetext{
${ }^{10}$ Ahmed Boa. The Impact of E-Commerce on the Development of Accounting Information Systems (Jijel: Jijel University, Facility of Trade, PHD Thesis, 2014),17-18.

11 Muhammad Abkar et al. "The Impact of E-Commerce on the Development of Accounting Information Systems" State Journal of Legal and Economic Studies 2/2 (June 2019), 229-247.
} 
divided into two parts: organizational and internal factors (represented in administrative factors), individual factors, operational factors trust, and technological factors. The external factors were identified in: government support, industry pressure, and competition between companies. ${ }^{12}$ Othman (2019).In another study it is found out that the effect of electronic accounting information system components on commercial banks in protecting e-commerce operations the study recommended the necessity of verifying the validity of the data during the introduction of the accounting information system, and the auditor's report should not be from the traditional and formal aspects only, taking into account the electronic requirements. ${ }^{13}$ Thakr, Rafidah and others (2018). Find out the positive effect of e-commerce on the development of information systems. E-commerce accounting information systems need to reevaluate the components and methods used to collect, store, and process data and then give it to those who can use it to make financial decisions. ${ }^{14}$ Al-Tanqari(2010). Focus on the extent to which business organizations exploit modern information technology and benefit from it in developing the accounting information systems used by them, which helps obtain information with speed, accuracy, and timing appropriate for decision-makers and those related to these organizations, whether from inside or outside the organization. ${ }^{15}$ Halas (2013) This study aimed to present the extent to which electronic accounting information systems contribute to making their outputs from accounting information, reports, and financial statement so that the qualitative characteristics of the accounting information are available to meet the needs of decision-makers.

\section{WHAT DISTINGUISHES THIS STUDY}

This study is characterized by the fact that it focused on the impact of electronic commerce on the development of accounting information systems for a selected sample of commercial companies in the governorates of Erbil, Dohuk, and Sulaymaniyah in Iraq. The development includes all the physical components such as modern equipment, as well as the human components of the workers in these companies and the extent of their training and qualification to keep pace with the operations that occur in light of E-Commerce.

12 Fatima Ajmal et al. "Model for Electronic Commerce Adoption for Small and Medium Sized Enterprises" International Journal of Innovation,Management and Technology 2/3(June 2012), 15-25.

13 Mohieddin OTHMAN et al "The Impact of the Components of the Accounting Information System on the Protection of E-commerce Operations of Banks Operating in Sudan". Journal of Economic, Administrative and Legal Sciences 2.11 (June 2018) 33-45

14 Rafidah Thakr. The Impact of Electronic Commerce on the Development of Accounting Information Systems (Tawa: Mnala University, Trade Facility, Master Thesis 2018), 9-10.

15 Hassan Abdul Hadi, The Role of Information Technology in Developing Accounting Information Systems" (Khartoum: Sudan University, Facultiees of Information Technology, PHD Thesis. 2010), 1-40. 


\section{DATA}

The research community consists of establishments and companies operating inthe commercial sector in the three governorates of Iraq, Dohuk, Erbil, andSulaymaniyah, for the year of 2021. We conducted the field study by distributing the research sample was chosen in the manner of a comprehensive survey method for some companies and establishments through and we are conducting the field study by distributing the questionnaire that was designed by them and which includes a group of questions that is asked to them.

\section{EMPRICAL RESULTS}

Recently, humanity has witnessed a great boom in the information technology field, starting with the emergence of automated accounts and electronic processing of data, then the emergence of the international information network, the Internet, which provided means of communication that were not available before. Its use resulted in the emergence of a new type of commerce called (electronic commerce), with its features and characteristics distinct from traditional trade. Moreover, the accounting profession had to keep pace with this accelerated development in the business environment. The emergence of electronic commerce resulted in the emergence of a new type of organization that has no specific location, or a hierarchical structure or a tangible physical entity whose existence depends on the network and electronic exchange of data, and this had a direct impact on the accounting information systems in terms of their design and operating procedures.

To display the results and analyze them clearly, the questionnaire was used as a method with common uses to collect data from the selected sample. The main objective of the research is achieved and through which the questions related to the presentation of the research problem are answered. The questionnaire for this research, as mentioned earlier, consists of three parts:

a. The first: It contains general information about (job degree, academic achievement, gender, and years of experience).

b. The second part: is about the focus of the research (the degree of accreditation of electronic commerce).

c. The third part: focuses on the impact of the degree of dependence on ecommerce in developing accounting information systems.

The five-point of Likart scale was used to measure the response of the studied sample to the second and third paragraphs of the questionnaire as follows: 
1. I do not strongly agree

2. I do not agree

3. Neutral

4. Agreed

5. Strongly agree

6. Response

The methods of statistical analysis differ according to the purpose of conducting them, as for this study, the statistical program (SPSS) is used to analyze the data and obtain results for all the questionnaire paragraphs of this research project, and the following statistical tools are used:

1. Percentages and Frequencies: are used to describe the degree of response of the research sample.

2. The arithmetic means and standard deviation: measures the importance of the paragraph for individuals of the sample, as the arithmetic mean is used for the study sample's answers to the questionnaire.

3. Correlation and regression coefficient: is used to measure the extent of the correlation between two variables or two phenomena.

Table (1): Summary of the sample

\begin{tabular}{|c|c|c|c|c|c|}
\hline \multicolumn{6}{|c|}{ Table of occurrences for the job degree } \\
\hline $\begin{array}{l}\text { Cumulative } \\
\text { percentage }\end{array}$ & $\begin{array}{l}\text { The valid } \\
\text { ratio }\end{array}$ & $\begin{array}{l}\text { The } \\
\text { ratio }\end{array}$ & Duplicates & \multicolumn{2}{|c|}{ Categories } \\
\hline 57.1 & 57.1 & 57.1 & 160 & Employee & \multirow{5}{*}{$\begin{array}{c}\text { Vali } \\
\text { d } \\
\text { resu } \\
\text { Its }\end{array}$} \\
\hline 82.1 & 25.0 & 25.0 & 70 & $\begin{array}{c}\text { Department } \\
\text { official }\end{array}$ & \\
\hline 96.4 & 14.3 & 14.3 & 40 & $\begin{array}{l}\text { Company } \\
\text { Director }\end{array}$ & \\
\hline \multirow[t]{2}{*}{100.0} & 3.6 & 3.6 & 10 & $\begin{array}{l}\text { Company } \\
\text { owner }\end{array}$ & \\
\hline & 100.0 & 100.0 & 280 & Total & \\
\hline
\end{tabular}




\begin{tabular}{|c|c|c|c|c|c|}
\hline \multicolumn{6}{|c|}{ Table of occurrences of academic achievement } \\
\hline $\begin{array}{l}\text { Cumulative } \\
\text { percentage }\end{array}$ & $\begin{array}{l}\text { The valid } \\
\text { ratio }\end{array}$ & $\begin{array}{l}\text { The } \\
\text { ratio }\end{array}$ & $\begin{array}{c}\text { Duplicate } \\
\text { s }\end{array}$ & \multicolumn{2}{|l|}{ Categories } \\
\hline 14.3 & 14.3 & 14.3 & 40 & $\begin{array}{c}\text { Intermediate or middle } \\
\text { school }\end{array}$ & \multirow{5}{*}{$\begin{array}{c}\text { Vali } \\
\text { d } \\
\text { resu } \\
\text { Its }\end{array}$} \\
\hline 100.0 & 85.7 & 85.7 & 240 & Institute or college & \\
\hline 100.0 & 0 & 0 & 0 & Postgraduate & \\
\hline \multirow[t]{2}{*}{100.0} & 0 & 0 & 0 & Other & \\
\hline & 100.0 & 100.0 & 280 & Total & \\
\hline
\end{tabular}

\begin{tabular}{|c|c|c|c|c|c|}
\hline \multicolumn{6}{|c|}{ Frequencies to determine the gender } \\
\hline $\begin{array}{l}\text { Cumulative } \\
\text { percentage }\end{array}$ & $\begin{array}{l}\text { The valid } \\
\text { ratio }\end{array}$ & $\begin{array}{l}\text { The } \\
\text { ratio }\end{array}$ & $\begin{array}{c}\text { Duplicate } \\
\text { s }\end{array}$ & \multicolumn{2}{|c|}{ Categories } \\
\hline 85.7 & 85.7 & 85.7 & 240 & Mention & \multirow{3}{*}{$\begin{array}{c}\text { Vali } \\
\text { d } \\
\text { resu } \\
\text { Its }\end{array}$} \\
\hline \multirow[t]{2}{*}{100.0} & 14.3 & 14.3 & 40 & Female & \\
\hline & 100.0 & 100.0 & 280 & Total & \\
\hline
\end{tabular}

\begin{tabular}{|c|c|c|c|c|c|}
\hline \multicolumn{6}{|c|}{ Duplications for field experience and practice } \\
\hline $\begin{array}{l}\text { Cumulative } \\
\text { percentage }\end{array}$ & $\begin{array}{l}\text { The valid } \\
\text { ratio }\end{array}$ & $\begin{array}{l}\text { The } \\
\text { ratio }\end{array}$ & $\begin{array}{l}\text { Duplicate } \\
\text { s }\end{array}$ & Categories & \\
\hline 14.3 & 14.3 & 14.3 & 40 & Less than 3 years & \multirow{5}{*}{$\begin{array}{c}\text { Vali } \\
\text { d } \\
\text { resu } \\
\text { Its }\end{array}$} \\
\hline 53.6 & 39.3 & 39.3 & 110 & From 3 to 5 years & \\
\hline 78.6 & 25.0 & 25.0 & 70 & From 6 to 10 years & \\
\hline \multirow[t]{2}{*}{100.0} & 21.4 & 21.4 & 60 & More than 10 years & \\
\hline & 100.0 & 100.0 & 280 & Total & \\
\hline
\end{tabular}

\section{The degree of dependence on electronic commerce}

The second part of the questionnaire concerns the collection of data from the selected sample. The focus has been on determining the degree of dependence on ecommerce in the selected companies of the research sample, like the table below (2) explains the descriptive analysis of the independent variable represented by the application of the above companies about the consequences of the application of ecommerce through the general average of the questions of the first part of the 
questionnaire, as it is proven that the largest percentage of the sample agreed with our questions for this part, as about $56 \%$ fully agreeing that these companies rely on ecommerce in the companies chosen as the research sample (those who agreed strongly $24 \%$ while the agreed $32 \%$ ). They agreed to the use of modern technology in the processes of selling, buying, marketing, displaying products, how to collect from customers, and using what is currently called the electronic banking service. The result was interesting for the arithmetic mean, where it appeared about 2.5. This can be explained by the fact that the results confirm that these companies are in favor of relying on e-commerce in the selected companies. Still they lack professionalism in applying and benefiting from it.

\section{Table (2) The degree of dependence on e-commerce for the studied sample}

\begin{tabular}{|c|c|c|c|c|c|c|c|c|c|c|c|c|c|c|}
\hline \multirow{3}{*}{$\begin{array}{l}\text { Depe } \\
\text { ndent } \\
\text { varia } \\
\text { ble }\end{array}$} & \multicolumn{12}{|c|}{ Level of evaluation } & \multirow{3}{*}{$\begin{array}{l}\text { Arith } \\
\text { metic } \\
\text { mean }\end{array}$} & \multirow{3}{*}{$\begin{array}{l}\text { Stand } \\
\text { ard } \\
\text { recog } \\
\text { nition }\end{array}$} \\
\hline & \multicolumn{2}{|c|}{$\begin{array}{c}1 \\
\text { Strongly } \\
\text { agreed }\end{array}$} & Agr & & neu & & Disa & & $\begin{array}{l}\text { Stron } \\
\text { disagr }\end{array}$ & & \multicolumn{2}{|c|}{$\begin{array}{c}\text { Total } \\
\text { iterations }\end{array}$} & & \\
\hline & $\begin{array}{c}\text { The } \\
\text { numb } \\
\text { er of } \\
\text { iterat } \\
\text { ions }\end{array}$ & $\begin{array}{l}\text { Perce } \\
\text { ntage }\end{array}$ & $\begin{array}{l}\text { The } \\
\text { num } \\
\text { ber } \\
\text { of } \\
\text { iterat } \\
\text { ions }\end{array}$ & $\begin{array}{l}\text { perce } \\
\text { ntage }\end{array}$ & $\begin{array}{l}\text { The } \\
\text { num } \\
\text { ber } \\
\text { of } \\
\text { iterat } \\
\text { ions }\end{array}$ & $\begin{array}{l}\text { perce } \\
\text { ntage }\end{array}$ & $\begin{array}{l}\text { The } \\
\text { num } \\
\text { ber } \\
\text { of } \\
\text { iterat } \\
\text { ions }\end{array}$ & $\begin{array}{l}\text { perce } \\
\text { ntage }\end{array}$ & $\begin{array}{c}\text { Th } \\
\text { num } \\
\text { ber } \\
\text { of } \\
\text { iterat } \\
\text { ions }\end{array}$ & $\begin{array}{l}\text { perce } \\
\text { ntage }\end{array}$ & $\begin{array}{l}\text { The } \\
\text { num } \\
\text { ber } \\
\text { of } \\
\text { iterat } \\
\text { ions }\end{array}$ & $\begin{array}{c}\text { The } \\
\text { numb } \\
\text { er of } \\
\text { iterat } \\
\text { ions }\end{array}$ & & \\
\hline VX1 & 110 & $39 \%$ & 50 & $18 \%$ & 50 & $18 \%$ & 70 & $25 \%$ & $\mathbf{0}$ & $0 \%$ & 280 & $100 \%$ & 2.29 & 1.243 \\
\hline VX2 & 90 & $32 \%$ & 70 & $25 \%$ & 60 & $21 \%$ & 60 & $21 \%$ & $\mathbf{0}$ & $0 \%$ & 280 & $100 \%$ & 2.32 & 1.156 \\
\hline VX3 & 90 & $32 \%$ & 70 & $25 \%$ & 40 & $14 \%$ & 40 & $14 \%$ & 40 & $14 \%$ & 280 & $100 \%$ & 2.54 & 1.453 \\
\hline VX4 & 30 & $11 \%$ & 120 & $43 \%$ & 30 & $11 \%$ & 40 & $14 \%$ & 60 & $21 \%$ & 280 & $100 \%$ & 2.93 & 1.386 \\
\hline VX5 & 70 & $25 \%$ & 80 & $29 \%$ & 20 & $7 \%$ & 100 & $36 \%$ & 10 & $4 \%$ & 280 & $100 \%$ & 2.64 & 1.311 \\
\hline VX6 & 30 & $11 \%$ & 70 & $25 \%$ & 90 & $32 \%$ & 80 & $29 \%$ & 10 & $4 \%$ & 280 & $100 \%$ & 2.89 & 1.066 \\
\hline VX7 & 30 & $11 \%$ & 80 & $29 \%$ & 70 & $25 \%$ & 50 & $18 \%$ & 50 & $18 \%$ & 280 & $100 \%$ & 3.04 & 1.29 \\
\hline VX8 & 70 & $25 \%$ & 120 & $43 \%$ & 40 & $14 \%$ & 30 & $11 \%$ & 20 & $7 \%$ & 280 & $100 \%$ & 2.32 & 1.188 \\
\hline VX9 & 80 & $29 \%$ & 110 & $39 \%$ & 10 & $4 \%$ & 80 & $29 \%$ & 0 & $0 \%$ & 280 & $100 \%$ & 2.32 & 1.188 \\
\hline VX10 & 80 & $29 \%$ & 130 & $46 \%$ & 30 & $11 \%$ & 30 & $11 \%$ & 10 & $4 \%$ & 280 & $100 \%$ & 2.14 & 1.079 \\
\hline $\begin{array}{l}\text { the } \\
\text { avera } \\
\text { ge }\end{array}$ & 70 & $24 \%$ & 90 & $32 \%$ & 40 & $16 \%$ & 60 & $21 \%$ & 20 & $7 \%$ & 280 & $100 \%$ & 2.54 & 1.24 \\
\hline
\end{tabular}

The results in the table indicate remarkable percentages. For example, we find in paragraphs (VX8) and (VX9) referred to in the questionnaire attached to this research that the percentage of reliance on e-commerce has reached a high standards.

Approximately 190 out of 280 of the sample agreed that (the company displays its products on e-marketing and social networking sites) and (the company uses modern means to promote its products through the great development of ecommerce), respectively, paragraphs (VX8) and (VX9). It is also worth noting that the 
percentage of agreement, whether firmly or only in support, reached $(75 \%)$ of the studied sample about the content of paragraph (VX10) appearing in the appendices of the questionnaire, which indicates (there is a continuous update in the electronic promotional means of the company). Furthermore, the results in the above table indicate a disagreeable opinion about the content of the phrase that (the number of clients increased when the company used e-mail and social communication as a basis for commercial transactions). The largest percentage of non-agreement, reaching (40\%) related to paragraph (VX5) appearing in the annexes of the form Questionnaire which is a dangerous indication of the extent to which customers accept to develop towards successful e-commerce.

\section{The Impact of E-Commerce Application on Accounting Information} Systems

Table (3) shows the indicator of the relationship between the application of ecommerce and the extent of its impact on accounting information systems. It is understood as a descriptive analysis of the effect of the independent variable on the dependent variable. It can be concluded that about $64 \%$ of the studied research sample agree on the effect of relying on e-commerce in accounting information systems, and about $17 \%$ do not agree with that, but about $20 \%$ are neutral. The results are explained in Table (2) below to the number of iterations of the agreement amounting to (230) of the sample, whose number is (280) about the content of (VY2), which indicates that $82 \%$ agreed that the (electronic commerce has a role in the ease and speed of understanding the accounting information of the beneficiaries). On the other hand, the percentage of disagreement is only $11 \%$. The results also indicate the agreement on the content of paragraph (VY1), which states that (electronic commerce has greatly contributed to the development of the accounting system in the company) by $(75 \%)$ and this means that there is a correlational relationship between the two research variables represented in e-commerce and accounting information systems. It is noticeable that the two numbered paragraphs (VY9) recorded the most significant percentage of conservatism by the studied sample, as they recorded a percentage of more than one-third and 35\%, which means that they are neutral that the cost of the accounting system decreased when using electronic commerce. 
Table (3) E-commerce and the extent of its impact on the accounting information systems of the studied sample

\begin{tabular}{|c|c|c|c|c|c|c|c|c|c|c|c|c|c|c|}
\hline \multicolumn{13}{|c|}{ Level of evaluation } & \multirow{4}{*}{\multicolumn{2}{|c|}{$\begin{array}{c}\text { Arit } \\
\text { hmet } \\
\text { ic } \\
\text { mea } \\
\text { n }\end{array}$}} \\
\hline \multirow{3}{*}{$\begin{array}{c}\text { Dep } \\
\text { ende } \\
\text { nt } \\
\text { varia } \\
\text { ble }\end{array}$} & \multicolumn{2}{|l|}{1} & \multicolumn{2}{|c|}{2} & \multicolumn{2}{|l|}{3} & \multicolumn{2}{|l|}{4} & \multicolumn{2}{|l|}{5} & \multirow{2}{*}{\multicolumn{2}{|c|}{$\begin{array}{l}\mathrm{T} \text { o t a } 1 \\
\text { iterations }\end{array}$}} & & \\
\hline & \multicolumn{2}{|c|}{$\begin{array}{l}\text { Strongly } \\
\text { agreed }\end{array}$} & \multicolumn{2}{|c|}{ Agreed } & \multicolumn{2}{|c|}{ Neutral } & \multicolumn{2}{|c|}{ disagree } & \multicolumn{2}{|c|}{$\begin{array}{l}\text { Strongly } \\
\text { disagreed }\end{array}$} & & & & \\
\hline & $\begin{array}{l}\text { The } \\
\text { num } \\
\text { ber } \\
\text { of } \\
\text { itera } \\
\text { tions }\end{array}$ & $\begin{array}{c}\text { perc } \\
\text { enta } \\
\text { ge }\end{array}$ & $\begin{array}{l}\text { The } \\
\text { num } \\
\text { ber } \\
\text { of } \\
\text { itera } \\
\text { tion } \\
\mathrm{s}\end{array}$ & $\begin{array}{c}\text { Perc } \\
\text { enta } \\
\text { ge }\end{array}$ & $\begin{array}{l}\text { The } \\
\text { num } \\
\text { ber } \\
\text { of } \\
\text { itera } \\
\text { tion } \\
\text { s }\end{array}$ & $\begin{array}{c}\text { Perc } \\
\text { enta } \\
\text { ge }\end{array}$ & $\begin{array}{l}\text { The } \\
\text { num } \\
\text { ber } \\
\text { of } \\
\text { itera } \\
\text { tion } \\
\text { s }\end{array}$ & $\begin{array}{c}\text { perc } \\
\text { enta } \\
\text { ge }\end{array}$ & $\begin{array}{l}\text { The } \\
\text { num } \\
\text { ber } \\
\text { of } \\
\text { itera } \\
\text { tion } \\
\text { s }\end{array}$ & $\begin{array}{c}\text { perc } \\
\text { enta } \\
\text { ge }\end{array}$ & $\begin{array}{l}\text { The } \\
\text { num } \\
\text { ber } \\
\text { of } \\
\text { itera } \\
\text { tion } \\
\mathrm{s}\end{array}$ & $\begin{array}{l}\text { The } \\
\text { num } \\
\text { ber } \\
\text { of } \\
\text { itera } \\
\text { tions }\end{array}$ & & \\
\hline VY1 & 110 & $39 \%$ & 100 & $36 \%$ & 30 & $11 \%$ & 40 & $14 \%$ & o & $0 \%$ & 280 & $100 \%$ & 2.00 & 1.054 \\
\hline VY2 & 100 & $36 \%$ & 130 & $46 \%$ & 20 & $7 \%$ & 30 & $11 \%$ & o & $0 \%$ & 280 & $100 \%$ & 1.93 & 0.94 \\
\hline VY3 & 50 & $18 \%$ & 130 & $46 \%$ & 40 & $14 \%$ & 40 & $14 \%$ & 20 & $7 \%$ & 280 & $100 \%$ & 2.46 & 1.17 \\
\hline VY4 & 80 & $29 \%$ & 80 & $29 \%$ & 80 & $29 \%$ & 40 & $14 \%$ & $\mathbf{0}$ & $0 \%$ & 280 & $100 \%$ & 2.29 & 1.049 \\
\hline VY5 & 70 & $25 \%$ & 90 & $32 \%$ & 50 & $18 \%$ & 40 & $14 \%$ & 30 & $11 \%$ & 280 & $100 \%$ & 2.54 & 1.319 \\
\hline VY6 & 100 & $36 \%$ & 70 & $25 \%$ & 80 & $29 \%$ & 20 & $7 \%$ & 10 & $4 \%$ & 280 & $100 \%$ & 2.18 & 1.124 \\
\hline VY7 & 30 & $11 \%$ & 130 & $46 \%$ & 50 & $18 \%$ & 70 & $25 \%$ & o & $0 \%$ & 280 & $100 \%$ & 2.57 & 0.997 \\
\hline VY8 & 90 & $32 \%$ & 110 & $39 \%$ & 50 & $18 \%$ & 30 & $11 \%$ & $\mathbf{0}$ & $0 \%$ & 280 & $100 \%$ & 2.07 & 0.979 \\
\hline VY9 & 80 & $29 \%$ & 40 & $14 \%$ & 110 & $39 \%$ & 50 & $18 \%$ & 0 & $0 \%$ & 280 & $100 \%$ & 2.46 & 1.105 \\
\hline VY10 & 100 & $36 \%$ & 90 & $32 \%$ & 50 & $18 \%$ & 30 & $11 \%$ & 10 & $4 \%$ & 280 & $100 \%$ & 2.14 & 1.145 \\
\hline $\begin{array}{l}\text { t h e } \\
\text { avera } \\
\text { ge }\end{array}$ & 80 & $29 \%$ & 100 & $35 \%$ & 60 & $20 \%$ & 40 & $14 \%$ & 10 & $3 \%$ & 280 & $100 \%$ & 2.26 & 1.09 \\
\hline
\end{tabular}

12. DISCUSS AND COMPARE THE RESULTS OF THE CURRENT RESEARCH WITH THE RESULTS OF PREVIOUS STUDIES

The main objective of the study is to identify the role of e-commerce in improving and developing the quality of the accounting information system in order to achieve this goal. We chose the category of employees, accountants, and managers in three governorates in Iraq as a research sample, and made a questionnaire and distributed it to them. The reason for choosing this category is that they work in companies and are familiar with all the developments that are happening in companies and through the nature of their work they have sufficient information about the state of the accounting information system as well as electronic commerce 
and we were able to obtain convincing answers and compare them with the results of previous studies for several issues.

E-commerce seeks to increase market reach and transcend geographical boundaries to reach new customers and build strong relationships with them to improve sales processes using speed and efficiency in doing business, as well as reduce costs. This finding is consistent with the study conducted by Thakr, Rafidah and others (2018).This study adds the findings that professional accountants have an awareness of professional ethics but should be supported through training in etransformation practices. Also, according to the results of this research, there is a direct relationship between electronic accounting and electronic commerce, and the use of the accounting information system will facilitate and benefit many parties inside and outside the company. They will obtain accurate accounting information and data. This affects costs, time and effort at a high speed, but accountants must develop their new electronic skills that came towards the accounting profession. This result is consistent with the study by Al-Tanqari (2010). Acceleration of all process systems procedures within the organization, which contributes to increasing the effectiveness of the organization's work and achieving significant cost savings through the provision of cheap international communication systems between organizations and the abandonment of a very large part of the documents. This result is consistent with the study conducted by Halas (2013).

The results discussed above show that this research has achieved its objectives. The results prove the fulfillment of the first hypothesis of the research, which is that economic transactions in the light of e-commerce increase the development of accounting information systems methods and affect their components so as to serve the satisfaction of companies.

\section{CONCLUSION}

1. The accounting information system is considered part of the total information system as it plays an important and influential role in providing the various levels of decision-making with ready, correct, accurate and timely information that helps them take multipe decisions. The system is generally based on several elements linked together to perform a specific function or several functions as it is governed by policies and procedures that are routinely followed. These procedures are monitored by the person responsible for the ecommerce system.

2. Electronic accounting has a direct relationship with business technology, changes in the economic or administrative fields. Any change that occurs in 
economic, administrative, social and technical activities is reflected in its impact on business activity and offset by an impact on accounting work and a quick response to keep pace with this event and address special problems in this change.

3. In order to obtain the accounting information system and contribute to achieving the goals of the companies in which it operates, it must take into consideration all the changes and developments that occur in the various areas surrounding its environment, especially with regard to the recent developments in the field of using modern information and communication technologies, of which electronic commerce is one of them.

4. E-commerce, as one of the modern variables in the world of business, imposed its impact on the accounting work by directing companies to mechanize the accounting work and train accountants to work on the computer to confront this change and its impact on the outputs of the accounting system (accounting information) by raising the level of the quality of this information. By providing them in a specific form, time, efficiency and effectiveness that serve information users and shortening the period of preparing and displaying financial statements on the Internet, and then supporting the convenience feature by providing information on time, as well as the ease of data entry due to the small size of these inputs and their complete change in instant systems.

5. E-commerce seeks to increase the scope of the market and transcend geographical boundaries to reach new customers and build strong relationships with them to improve sales processes using speed and efficiency in doing business in addition to reducing costs, effort, and time.

6. E-commerce contributes to achieving multiple advantages for companies and can be used to achieve a huge amount of process systems and implement some of the organization's functions such as building pages and websites for communication between the company and its customers and advertising for the company's products, receiving customer requests and suggestions quickly and responding to them on time.

7. The emergence of multinational companies and the joining of many companies to work in the light of e-commerce requires accounting information systems to re-evaluate its components and methods used in collecting, storing, and processing data, and then delivering it to the parties that can rely on it in making multiple decisions and companies operating under E-commerce requires attention to the human cadre (represented by individuals responsible 
for the work of accounting information systems) and the development of their knowledge skills in the areas of using information technology methods in order to be able to deal with them and achieve the benefit of their use in the field of accounting information systems work.

8. Working in the light of electronic commerce will affect the basic components of accounting information systems, represented by: the documentary group, the book group, the accounts manual, the group of reports and financial statements, which requires the need to take into account these effects and their implications for the design process of accounting information systems.

\section{RECOMMENDATIONS}

In this part of the study, we suggest that commercial companies should make their efforts to rely on e-commerce and develop the accounting information system for obtaining an electronic accounting program to suit the e-commerce requirements of these companies. Where the study made some proposals:

1. Setting an accounting standard that includes a specific scope for electronic commerce transactions, in which the formula for preparing and displaying accounting information for the electronic commerce process is available.

2. As a result of the economic transformation that Iraq is going through and the openness to various fields, especially electronic commerce, it is necessary to take advantage of this activity and include it within commercial practices and provide all its requirements in order to promote and revive the economy and keep pace with all changes to join global developments.

3. The management of the company must develop all the technical means used in the accounting information system periodically and continuously, as well as the need to pay attention to the continuous training of accountants, which contributes to keeping pace with developments in the economic field in the light of e-commerce.

4. All companies must obtain an electronic accounting information system. This is a crucial step to obtain accurate data and information and disclose it to the beneficiaries of the accounting information. This means having a central database through which the greatest benefit in the work of the system can be achieved.

5. Orientation towards electronic commerce means obtaining information very quickly, communicating the resulting information, and benefiting from the 
services arising from the spread of the search for advanced services that can be provided to ensure that these systems continue to maintain their effectiveness and increase their efficiency.

\section{RESEARCH LIMITATIONS}

It is clear that the objective of this study is to show the impact of electronic commerce on the accounting information system for the purpose of data collection. Companies and this in the year 2021 and we faced many obstacles, the most important of which is that employees in companies did not help us in responding to a questionnaire and the short time concurrent with studying. Continuous commitment to other study subjects in addition, we were faced with the lack of sources that, if available, are supposed to provide us with more literature on research topics. The lack of a detailed and accurate database of accounting information on the research community also had an impact on the better conduct of this research. In the end, we were able to reach study's goal,and we wrote the results of the research and suggestions as well.

\section{REFERENCES}

Abdul Hadi, Hassan. The Role of Information Technology in Developing Accounting Information Systems. Khartoum: Sudan University, Facultiees of Information Technology, PHD Thesis. 2010.

Abkar, Muhammad et al. "The Impact of E-Commerce on the Development of Accounting Information Systems". State Journal of Legal and Economic Studies , 2/2 (June 2019) 229-247.

Ajmal, Fatimaan et al. "Model for Electronic Commerce Adoption for Small and Medium Sized Enterprises", International Journal of Innovation,Management and Technology 2/3(June 2012), 15-25.

Al Faraj, Muhammad Abd Hussain. Accounting Information Systems. Amman: Wael Publishing House, 2. Edition, 2009.

Al Samarrai, Abdul Zahid - Al Abdali, Samir. The Department of Sales and Electronic Sales. Amman: Ithraa House for Publishing, 1. Edition, 2011.

Boa, Ahmed. The Impact of E-Commerce on the Development of Accounting Information Systems. Jijel: Jijel University, Facility of Trade, PHD Thesis, 2014.

Bograra, Shfiya. The Importance of the Accounting Information System in Making Strategic Decisions. Duhok: Jihan University, Institute of Administrative, Master Thesis, 2020. 
Das, Ikram. The Legal System for E-commerce Contracts. Szaq: MohamedCherif Messaadia University, Facility of Law, Master Thesis, 2020.

Halasa, Samir Ramadan. The Extent of Suitability of the Outputs of Electronic Accounting Information Systems to the Requirements of Administrative Decisionmakers. Gaza: Gaza University, Faculties of Accounting, Master Thesis, 2013.

Kaiikh, Faisal. The Effect of Using Electronic Accounting Information Systems on Improving Employee Performance. Tripoli, Kaja University, Institute of Administrative, Master Thesis, 2021.

Khalil, Nasser. Electronic Commerce. Amman: Osama House for Publishing, 3. Edition, 2009.

Othman, Mohieddin et al. "The Impact of the Components of the Accounting Information System on the Protection of E-commerce Operations of Banks Operating in Sudan". Journal of Economic, Administrative and Legal Sciences, 2.11 (Joun 2018), 33-45

Qasim, Abdul Razzaq Muhammad. Analysis and Design of Accounting Information Systems. Amman: Dar Al Thaqafa, 1. Edition, 2009.

Shouthari, Shoaib. The Effect of the Accounting Information System in Improving the Quality of Accounting Information. Algeria: Messila University, Institute of Administrative, Master Thesis, 2018.

Thakr, Rafidah. The Impact of Electronic Commerce on the Development of Accounting Information Systems. Tawa: Mnala University,Trade Facility, Master Thesis, 2018.

Yusef, Hajjaj. E-Marketing: Skills and Arts. Hebron: Dar Al-Walid, 2nd. Edition, 2010. 


\section{Accessories}

\section{The questionnaire}

This questionnaire has three parts:

Part one: General data:
Employe
e
Department
official
C o m p a n y
Director
Company
owner

Second: Academic Achievement:

Interme

diate or middle

$\square$ Institute or college

$\square$ Postgraduat e studies

$\square$ Other

school

\section{Third: Gender:}

male $\quad \square$ female

Fourth: Field Service (Years of Service):
Less than 3
years
From 3 to 5
years
From 6 to
10 years
M o r e
than 10
years

Part two: data for the independent variable: electronic commerce:

\begin{tabular}{|l|l|c|c|c|c|c|}
\hline \multicolumn{7}{|c|}{ Part two: data for the independent variable: electronic commerc: } \\
\hline NO & $\begin{array}{c}\mathbf{1} \\
\text { Contents }\end{array}$ & $\begin{array}{c}\mathbf{2} \\
\text { y } \\
\text { agreed }\end{array}$ & $\begin{array}{c}\mathbf{3} \\
\text { Agree }\end{array}$ & $\begin{array}{c}\text { neutr } \\
\text { al }\end{array}$ & $\begin{array}{c}\mathbf{4} \\
\text { disagre } \\
\text { e }\end{array}$ & $\begin{array}{c}\text { Strongl } \\
\text { y } \\
\text { disagree } \\
\text { d }\end{array}$ \\
\hline 1 & $\begin{array}{l}\text { The company uses its } \\
\text { trad e p o li c y } \\
\text { electronically in all } \\
\text { buying and selling } \\
\text { operations. }\end{array}$ & & \\
\hline
\end{tabular}




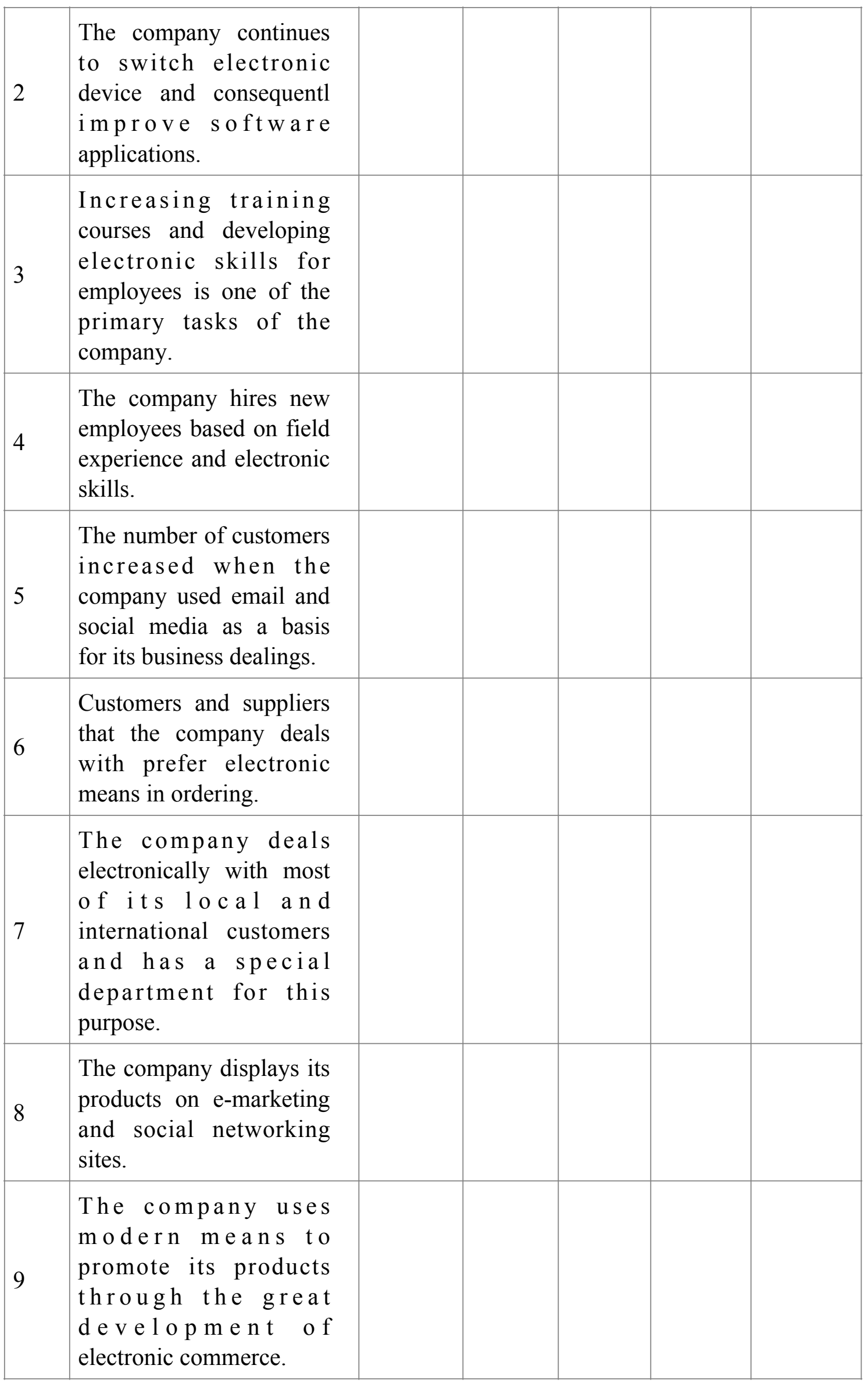




\begin{tabular}{|l|l|l|l|l|}
\hline 10 & $\begin{array}{l}\text { There is a constant } \\
\text { update in the company' } \\
\text { electronic promotional } \\
\text { tools. }\end{array}$ & & & \\
\hline
\end{tabular}

\begin{tabular}{|c|c|c|c|c|c|c|}
\hline & $\begin{array}{l}\text { The third part: The effect } \\
\text { variable: The effect of eled } \\
\text { systems: }\end{array}$ & $\begin{array}{l}\text { the ind } \\
\text { conic co }\end{array}$ & $\begin{array}{l}\text { menden } \\
\text { merce }\end{array}$ & ariab & $\begin{array}{l}\text { on the } \\
\text { ting in }\end{array}$ & $\begin{array}{l}\text { endent } \\
\text { mation }\end{array}$ \\
\hline NO & Contents & $\begin{array}{c}1 \\
\text { Strong } \\
\text { ly } \\
\text { agreed }\end{array}$ & $\begin{array}{c}2 \\
\text { Agree } \\
\mathbf{d}\end{array}$ & $\begin{array}{c}3 \\
\text { neutr } \\
\text { al }\end{array}$ & $\begin{array}{c}4 \\
\text { disagr } \\
\text { ee }\end{array}$ & $\begin{array}{c}5 \\
\text { Strongl } \\
y \\
\text { disagre } \\
\text { ed }\end{array}$ \\
\hline 1 & $\begin{array}{l}\text { E-commerce contributed } \\
\text { greatly to the development } \\
\text { of the c o m p a n y's } \\
\text { accounting system. }\end{array}$ & & & & & \\
\hline 2 & $\begin{array}{l}\text { E-commerce has a role in } \\
\text { the ease and speed of } \\
\text { understanding the } \\
\text { accounting information of } \\
\text { the beneficiaries. }\end{array}$ & & & & & \\
\hline 3 & $\begin{array}{l}\text { The use of electronic } \\
\text { commerce has changed the } \\
\text { components and design of } \\
\text { the company's accounting } \\
\text { information system. }\end{array}$ & & & & & \\
\hline 4 & $\begin{array}{l}\text { The company has an } \\
\text { advanced accounting } \\
\text { information system that is } \\
\text { compatible with the } \\
\text { development of electronic } \\
\text { commerce. }\end{array}$ & & & & & \\
\hline
\end{tabular}




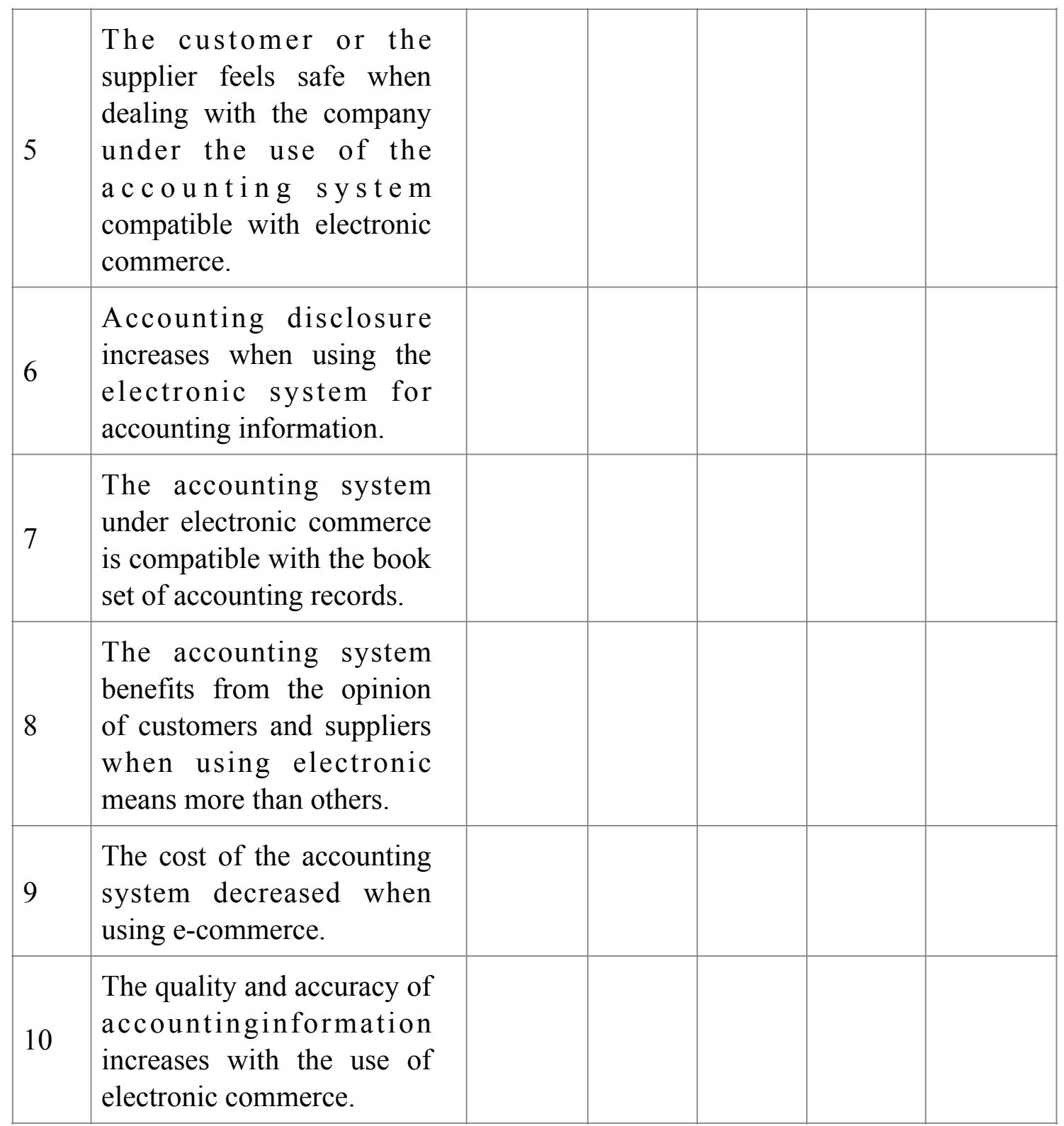

\begin{tabular}{|c|c|c|c|c|c|}
\hline \multicolumn{6}{|c|}{ Table of occurrences for the job degree } \\
\hline $\begin{array}{l}\text { Cumulative } \\
\text { percentage }\end{array}$ & $\begin{array}{c}\text { The valid } \\
\text { ratio }\end{array}$ & $\begin{array}{l}\text { The } \\
\text { ratio }\end{array}$ & $\begin{array}{c}\text { Duplicat } \\
\text { es }\end{array}$ & Catego & \\
\hline 57.1 & 57.1 & 57.1 & 160 & Employee & \multirow{4}{*}{$\begin{array}{c}\text { Vali } \\
\text { d } \\
\text { res } \\
\text { ults }\end{array}$} \\
\hline 82.1 & 25.0 & 25.0 & 70 & $\begin{array}{l}\text { Departme } \\
\text { nt official }\end{array}$ & \\
\hline 96.4 & 14.3 & 14.3 & 40 & $\begin{array}{c}\text { Company } \\
\text { Director }\end{array}$ & \\
\hline 100.0 & 3.6 & 3.6 & 10 & $\begin{array}{c}\text { Company } \\
\text { owner }\end{array}$ & \\
\hline
\end{tabular}




\begin{tabular}{|l|l|l|l|l|}
\hline & 100.0 & 100.0 & 280 & Total \\
\hline
\end{tabular}

\begin{tabular}{|c|c|c|c|c|c|}
\hline \multicolumn{6}{|c|}{ Table of occurrences of academic achievement } \\
\hline $\begin{array}{l}\text { Cumulativ } \\
\text { e } \\
\text { percentage }\end{array}$ & $\begin{array}{l}\text { The } \\
\text { valid } \\
\text { ratio }\end{array}$ & $\begin{array}{l}\text { The } \\
\text { ratio }\end{array}$ & $\begin{array}{c}\text { Duplicat } \\
\text { es }\end{array}$ & Categories & \\
\hline 14.3 & 14.3 & 14.3 & 40 & $\begin{array}{l}\text { Intermediate or } \\
\text { middle school }\end{array}$ & \multirow{5}{*}{$\begin{array}{c}\text { Vali } \\
\text { d } \\
\text { res } \\
\text { ults }\end{array}$} \\
\hline 100.0 & 85.7 & 85.7 & 240 & Institute or college & \\
\hline 100.0 & 0 & 0 & 0 & Postgraduate & \\
\hline \multirow[t]{2}{*}{100.0} & 0 & 0 & 0 & Other & \\
\hline & 100.0 & 100.0 & 280 & Total & \\
\hline
\end{tabular}

\begin{tabular}{|c|c|c|c|c|c|}
\hline \multicolumn{7}{|c|}{ Table of frequencies to determine the gender } \\
\hline $\begin{array}{c}\text { Cumulativ } \\
\text { e } \\
\text { percentage }\end{array}$ & $\begin{array}{c}\text { The } \\
\text { valid } \\
\text { ratio }\end{array}$ & $\begin{array}{c}\text { The } \\
\text { ratio }\end{array}$ & $\begin{array}{c}\text { Duplicat } \\
\text { es }\end{array}$ & \multicolumn{2}{|c|}{ Categories } \\
\hline 85.7 & 85.7 & 85.7 & 240 & Mention & Vali \\
d \\
res \\
ults
\end{tabular}

\begin{tabular}{|c|c|c|c|c|c|}
\hline \multicolumn{6}{|c|}{ Table of duplications for field experience and practice } \\
\hline $\begin{array}{l}\text { Cumulativ } \\
\text { e } \\
\text { percentage }\end{array}$ & $\begin{array}{l}\text { The } \\
\text { valid } \\
\text { ratio }\end{array}$ & $\begin{array}{c}\text { The } \\
\text { ratio }\end{array}$ & $\begin{array}{c}\text { Duplicat } \\
\text { es }\end{array}$ & Categories & \\
\hline 14.3 & 14.3 & 14.3 & 40 & Less than 3 years & \multirow{5}{*}{$\begin{array}{c}\text { Vali } \\
\text { d } \\
\text { res } \\
\text { ults }\end{array}$} \\
\hline 53.6 & 39.3 & 39.3 & 110 & From 3 to 5 years & \\
\hline 78.6 & 25.0 & 25.0 & 70 & From 6 to 10 years & \\
\hline \multirow[t]{2}{*}{100.0} & 21.4 & 21.4 & 60 & More than 10 years & \\
\hline & 100.0 & 100.0 & 280 & Total & \\
\hline
\end{tabular}


A general descriptive analysis of the independent variable Descriptive Statistics VX's

\begin{tabular}{|c|c|c|c|c|c|}
\hline \multicolumn{6}{|c|}{$\begin{array}{l}\text { General descriptive analysis of the independent variable Descriptive } \\
\text { Statistics VX's }\end{array}$} \\
\hline $\begin{array}{l}\text { standard } \\
\text { deviation }\end{array}$ & $\begin{array}{l}\text { Arithmetic } \\
\text { mean }\end{array}$ & $\begin{array}{l}\text { the } \\
\text { highest } \\
\text { rate }\end{array}$ & $\begin{array}{c}\text { Mini } \\
\text { mu } \\
\text { m }\end{array}$ & $\begin{array}{c}\text { the } \\
\text { numbe } \\
\text { r }\end{array}$ & variable \\
\hline 1.243 & 2.29 & 40 & 10 & 280 & VX1 \\
\hline 1.156 & 2.32 & 40 & 10 & 280 & VX2 \\
\hline 1.453 & 2.54 & 50 & 10 & 280 & VX3 \\
\hline 1.386 & 2.93 & 50 & 10 & 280 & VX4 \\
\hline 1.311 & 2.64 & 50 & 10 & 280 & VX5 \\
\hline 1.066 & 2.89 & 50 & 10 & 280 & VX6 \\
\hline 1.290 & 3.04 & 50 & 10 & 280 & VX7 \\
\hline 1.188 & 2.32 & 50 & 10 & 280 & VX8 \\
\hline 1.188 & 2.32 & 40 & 10 & 280 & VX9 \\
\hline \multirow[t]{2}{*}{1.079} & 2.14 & 50 & 10 & 280 & VX10 \\
\hline & & & & 280 & $\begin{array}{c}\text { The } \\
\text { valid } \\
\text { number }\end{array}$ \\
\hline
\end{tabular}


General descriptive analysis of the dependent variable Descriptive Statistics VY's

\begin{tabular}{|c|c|c|c|c|c|}
\hline \multicolumn{6}{|c|}{ General descriptive statistics of the dependent variable Descriptive } \\
\hline $\begin{array}{c}\text { Statistics VY's } \\
\text { standard } \\
\text { deviation }\end{array}$ & $\begin{array}{c}\text { Arithmet } \\
\text { ic mean }\end{array}$ & $\begin{array}{c}\text { the } \\
\text { highest } \\
\text { rate }\end{array}$ & $\begin{array}{c}\text { Mini } \\
\text { mum }\end{array}$ & $\begin{array}{c}\text { the } \\
\text { numbe } \\
\text { r }\end{array}$ & Variable \\
\hline 1.054 & 2.00 & 40 & 10 & 280 & VY1 \\
\hline .940 & 1.93 & 40 & 10 & 280 & VY2 \\
\hline 1.170 & 2.46 & 50 & 10 & 280 & VY3 \\
\hline 1.049 & 2.29 & 40 & 10 & 280 & VY4 \\
\hline 1.319 & 2.54 & 50 & 10 & 280 & VY5 \\
\hline 1.124 & 2.18 & 50 & 10 & 280 & VY6 \\
\hline .997 & 2.57 & 40 & 10 & 280 & VY7 \\
\hline .979 & 2.07 & 40 & 10 & 280 & VY8 \\
\hline 1.105 & 2.46 & 40 & 10 & 280 & VY9 \\
\hline 1.145 & 2.14 & 50 & 10 & 280 & VY10 \\
\hline & & & & 280 & The valid \\
& & & & & \\
\hline
\end{tabular}


Summary of general occurrences of the independent variable Descriptive Statistics VX'

\begin{tabular}{|c|c|c|c|c|c|c|c|c|c|c|c|}
\hline \multicolumn{12}{|c|}{$\begin{array}{l}\text { Summary of general occurrences of the independent variable Descriptive } \\
\text { Statistics VX's }\end{array}$} \\
\hline $\begin{array}{l}\mathrm{VX} \\
10\end{array}$ & $\begin{array}{c}\text { VX } \\
9\end{array}$ & $\begin{array}{l}\mathbf{V X} \\
8\end{array}$ & $\begin{array}{c}\text { VX } \\
7\end{array}$ & $\begin{array}{c}\mathbf{V X} \\
6\end{array}$ & $\begin{array}{c}\mathbf{V X} \\
5\end{array}$ & $\begin{array}{l}\mathrm{VX} \\
4\end{array}$ & $\begin{array}{c}\mathbf{V X} \\
3\end{array}$ & $\begin{array}{c}\mathbf{V X} \\
2\end{array}$ & $\begin{array}{c}\mathbf{V X} \\
\mathbf{1}\end{array}$ & \multicolumn{2}{|c|}{ the details } \\
\hline 280 & 280 & 280 & 280 & 280 & 280 & 280 & 280 & 280 & 280 & $\begin{array}{l}\text { Valid } \\
\text { result }\end{array}$ & \multirow{2}{*}{$\begin{array}{l}\text { the } \\
\text { nu } \\
\text { mb } \\
\text { er }\end{array}$} \\
\hline 0 & 0 & 0 & 0 & 0 & 0 & 0 & 0 & 0 & 0 & $\begin{array}{c}\text { Invalid } \\
\text { result }\end{array}$ & \\
\hline $\begin{array}{c}2.1 \\
4\end{array}$ & $\begin{array}{c}2.3 \\
2\end{array}$ & $\begin{array}{c}2.3 \\
2\end{array}$ & $\begin{array}{c}3.0 \\
4\end{array}$ & $\begin{array}{c}2.8 \\
9\end{array}$ & $\begin{array}{c}2.6 \\
4\end{array}$ & $\begin{array}{c}2.9 \\
3\end{array}$ & $\begin{array}{c}2.5 \\
4\end{array}$ & $\begin{array}{c}2.3 \\
2\end{array}$ & $\begin{array}{c}2.2 \\
9\end{array}$ & \multicolumn{2}{|c|}{$\begin{array}{c}\text { Arithmetic } \\
\text { mean }\end{array}$} \\
\hline $\begin{array}{l}1.0 \\
79\end{array}$ & $\begin{array}{l}1.1 \\
88\end{array}$ & $\begin{array}{l}1.1 \\
88\end{array}$ & $\begin{array}{l}1.2 \\
90\end{array}$ & $\begin{array}{l}1.0 \\
66\end{array}$ & $\begin{array}{c}1.3 \\
11\end{array}$ & $\begin{array}{l}1.3 \\
86\end{array}$ & $\begin{array}{l}1.4 \\
53\end{array}$ & $\begin{array}{l}1.1 \\
56\end{array}$ & $\begin{array}{l}1.2 \\
43\end{array}$ & \multicolumn{2}{|c|}{$\begin{array}{l}\text { standard } \\
\text { deviation }\end{array}$} \\
\hline $\begin{array}{l}1.0 \\
31\end{array}$ & $\begin{array}{c}.46 \\
0\end{array}$ & $\begin{array}{c}.88 \\
8\end{array}$ & $\begin{array}{c}15 \\
2\end{array}$ & $\begin{array}{l}-.1 \\
68\end{array}$ & $\begin{array}{c}.08 \\
9\end{array}$ & $\begin{array}{c}.40 \\
6\end{array}$ & $\begin{array}{c}.50 \\
9\end{array}$ & $\begin{array}{c}.23 \\
9\end{array}$ & $\begin{array}{l}.28 \\
2\end{array}$ & \multicolumn{2}{|c|}{ Skewness } \\
\hline $\begin{array}{c}.44 \\
1\end{array}$ & $\begin{array}{c}.44 \\
1\end{array}$ & $\begin{array}{c}.44 \\
1\end{array}$ & $\begin{array}{c}.44 \\
1\end{array}$ & $\begin{array}{c}.44 \\
1\end{array}$ & $\begin{array}{c}.44 \\
1\end{array}$ & $\begin{array}{c}.44 \\
1\end{array}$ & $\begin{array}{c}.44 \\
1\end{array}$ & $\begin{array}{c}.44 \\
1\end{array}$ & $\begin{array}{c}.44 \\
1\end{array}$ & \multicolumn{2}{|c|}{$\begin{array}{c}\text { Error } \\
\text { criterion for } \\
\text { torsion } \\
\text { modifier }\end{array}$} \\
\hline
\end{tabular}

Frequency tables for sub-paragraphs of the independent variable Frequency Table of VX's

\begin{tabular}{|c|c|c|c|c|c|}
\hline \multicolumn{6}{|c|}{ Table of occurrences of the sub-independent variable VX1 } \\
\hline $\begin{array}{l}\text { Cumulative } \\
\text { percentage }\end{array}$ & $\begin{array}{c}\text { The valid } \\
\text { ratio }\end{array}$ & $\begin{array}{l}\text { The } \\
\text { ratio }\end{array}$ & $\begin{array}{c}\text { Duplicat } \\
\text { es }\end{array}$ & \multicolumn{2}{|c|}{ Categories } \\
\hline 39.3 & 39.3 & 39.3 & 110 & $\begin{array}{c}\text { Strongly } \\
\text { agreed }\end{array}$ & \multirow{5}{*}{$\begin{array}{c}\text { Vali } \\
\text { d } \\
\text { res } \\
\text { ults }\end{array}$} \\
\hline 57.1 & 17.9 & 17.9 & 50 & Agreed & \\
\hline 75.0 & 17.9 & 17.9 & 50 & Neutral & \\
\hline \multirow[t]{2}{*}{100.0} & 25.0 & 25.0 & 70 & Disagree & \\
\hline & 100.0 & 100.0 & 280 & Total & \\
\hline
\end{tabular}




\begin{tabular}{|c|c|c|c|c|c|}
\hline \multicolumn{6}{|c|}{ Table of occurrences of the sub-independent variable VX2 } \\
\hline $\begin{array}{l}\text { Cumulative } \\
\text { percentage }\end{array}$ & $\begin{array}{c}\text { The valid } \\
\text { ratio }\end{array}$ & $\begin{array}{l}\text { The } \\
\text { ratio }\end{array}$ & $\begin{array}{c}\text { Duplicat } \\
\text { es }\end{array}$ & \multicolumn{2}{|c|}{ Categories } \\
\hline 32.1 & 32.1 & 32.1 & 90 & $\begin{array}{c}\text { Strongly } \\
\text { agreed }\end{array}$ & \multirow{5}{*}{$\begin{array}{c}\text { Vali } \\
\text { d } \\
\text { res } \\
\text { ults }\end{array}$} \\
\hline 57.1 & 25.0 & 25.0 & 70 & Agreed & \\
\hline 78.6 & 21.4 & 21.4 & 60 & Neutral & \\
\hline \multirow[t]{2}{*}{100.0} & 21.4 & 21.4 & 60 & Disagree & \\
\hline & 100.0 & 100.0 & 280 & Total & \\
\hline
\end{tabular}

\begin{tabular}{|c|c|c|c|c|c|}
\hline \multicolumn{6}{|c|}{ Table of occurrences of the sub-independent variable VX3 } \\
\hline $\begin{array}{l}\text { Cumulative } \\
\text { percentage }\end{array}$ & $\begin{array}{c}\text { The valid } \\
\text { ratio }\end{array}$ & $\begin{array}{l}\text { The } \\
\text { ratio }\end{array}$ & $\begin{array}{c}\text { Duplicat } \\
\text { es }\end{array}$ & \multicolumn{2}{|c|}{ Categories } \\
\hline 32.1 & 32.1 & 32.1 & 90 & $\begin{array}{c}\text { Strongly } \\
\text { agreed }\end{array}$ & \multirow{6}{*}{$\begin{array}{c}\text { Vali } \\
\text { d } \\
\text { res } \\
\text { ults }\end{array}$} \\
\hline 57.1 & 25.0 & 25.0 & 70 & Agreed & \\
\hline 71.4 & 14.3 & 14.3 & 40 & Neutral & \\
\hline 85.7 & 14.3 & 14.3 & 40 & Disagree & \\
\hline \multirow[t]{2}{*}{100.0} & 14.3 & 14.3 & 40 & $\begin{array}{l}\text { Strongly } \\
\text { disagreed }\end{array}$ & \\
\hline & 100.0 & 100.0 & 280 & Total & \\
\hline
\end{tabular}

\begin{tabular}{|c|c|c|c|c|c|}
\hline \multicolumn{6}{|c|}{ Table of occurrences of the sub-independent variable VX4 } \\
\hline $\begin{array}{c}\text { Cumulative } \\
\text { percentage }\end{array}$ & $\begin{array}{c}\text { The valid } \\
\text { ratio }\end{array}$ & $\begin{array}{c}\text { The } \\
\text { ratio }\end{array}$ & $\begin{array}{c}\text { Duplicat } \\
\text { es }\end{array}$ & \multicolumn{2}{|c|}{ Categories } \\
\hline 10.7 & 10.7 & 10.7 & 30 & $\begin{array}{c}\text { Strongly } \\
\text { agreed }\end{array}$ & \\
\hline 53.6 & 42.9 & 42.9 & 120 & Agreed & Vali \\
d \\
res \\
..t.
\end{tabular}




\begin{tabular}{|l|c|c|c|c|}
\hline 100.0 & 21.4 & 21.4 & 60 & $\begin{array}{c}\text { Strongly } \\
\text { disagreed }\end{array}$ \\
\hline & $\mathbf{1 0 0 . 0}$ & $\mathbf{1 0 0 . 0}$ & $\mathbf{2 8 0}$ & Total \\
\hline
\end{tabular}

\begin{tabular}{|c|c|c|c|c|c|}
\hline \multicolumn{6}{|c|}{ Table of occurrences of the sub-independent variable VX5 } \\
\hline $\begin{array}{l}\text { Cumulative } \\
\text { percentage }\end{array}$ & $\begin{array}{l}\text { The valid } \\
\text { ratio }\end{array}$ & $\begin{array}{l}\text { The } \\
\text { ratio }\end{array}$ & $\begin{array}{l}\text { Duplicat } \\
\text { es }\end{array}$ & Catego & \\
\hline 25.0 & 25.0 & 25.0 & 70 & $\begin{array}{c}\text { Strongly } \\
\text { agreed }\end{array}$ & \multirow{6}{*}{$\begin{array}{c}\text { Vali } \\
\text { d } \\
\text { res } \\
\text { ults }\end{array}$} \\
\hline 53.6 & 28.6 & 28.6 & 80 & Agreed & \\
\hline 60.7 & 7.1 & 7.1 & 20 & Neutral & \\
\hline 96.4 & 35.7 & 35.7 & 100 & Disagree & \\
\hline \multirow[t]{2}{*}{100.0} & 3.6 & 3.6 & 10 & $\begin{array}{l}\text { Strongly } \\
\text { disagreed }\end{array}$ & \\
\hline & 100.0 & 100.0 & 280 & Total & \\
\hline
\end{tabular}

\begin{tabular}{|c|c|c|c|c|c|}
\hline \multicolumn{6}{|c|}{ Table of occurrences of the sub-independent variable VX6 } \\
\hline $\begin{array}{l}\text { Cumulative } \\
\text { percentage }\end{array}$ & $\begin{array}{l}\text { The valid } \\
\text { ratio }\end{array}$ & $\begin{array}{l}\text { The } \\
\text { ratio }\end{array}$ & $\begin{array}{c}\text { Duplicat } \\
\text { es }\end{array}$ & \multicolumn{2}{|c|}{ Categories } \\
\hline 10.7 & 10.7 & 10.7 & 30 & $\begin{array}{c}\text { Strongly } \\
\text { agreed }\end{array}$ & \multirow{6}{*}{$\begin{array}{c}\text { Vali } \\
\text { d } \\
\text { res } \\
\text { ults }\end{array}$} \\
\hline 35.7 & 25.0 & 25.0 & 70 & Agreed & \\
\hline 67.9 & 32.1 & 32.1 & 90 & Neutral & \\
\hline 96.4 & 28.6 & 28.6 & 80 & Disagree & \\
\hline \multirow[t]{2}{*}{100.0} & 3.6 & 3.6 & 10 & $\begin{array}{c}\text { Strongly } \\
\text { disagreed }\end{array}$ & \\
\hline & 100.0 & 100.0 & 280 & Total & \\
\hline
\end{tabular}




\begin{tabular}{|c|c|c|c|c|c|}
\hline \multicolumn{6}{|c|}{ Table of occurrences of the sub-independent variable VX7 } \\
\hline $\begin{array}{l}\text { Cumulative } \\
\text { percentage }\end{array}$ & $\begin{array}{c}\text { The valid } \\
\text { ratio }\end{array}$ & $\begin{array}{l}\text { The } \\
\text { ratio }\end{array}$ & $\begin{array}{c}\text { Duplicat } \\
\text { es }\end{array}$ & \multicolumn{2}{|c|}{ Categories } \\
\hline 10.7 & 10.7 & 10.7 & 30 & $\begin{array}{c}\text { Strongly } \\
\text { agreed }\end{array}$ & \multirow{6}{*}{$\begin{array}{c}\text { Vali } \\
\text { d } \\
\text { res } \\
\text { ults }\end{array}$} \\
\hline 39.3 & 28.6 & 28.6 & 80 & Agreed & \\
\hline 64.3 & 25.0 & 25.0 & 70 & Neutral & \\
\hline 82.1 & 17.9 & 17.9 & 50 & Disagree & \\
\hline \multirow[t]{2}{*}{100.0} & 17.9 & 17.9 & 50 & $\begin{array}{l}\text { Strongly } \\
\text { disagreed }\end{array}$ & \\
\hline & 100.0 & 100.0 & 280 & Total & \\
\hline
\end{tabular}

\begin{tabular}{|c|c|c|c|c|c|}
\hline \multicolumn{6}{|c|}{ Table of occurrences of the sub-independent variable VX8 } \\
\hline $\begin{array}{l}\text { Cumulative } \\
\text { percentage }\end{array}$ & $\begin{array}{c}\text { The valid } \\
\text { ratio }\end{array}$ & $\begin{array}{l}\text { The } \\
\text { ratio }\end{array}$ & $\begin{array}{c}\text { Duplicat } \\
\text { es }\end{array}$ & \multicolumn{2}{|c|}{ Categories } \\
\hline 25.0 & 25.0 & 25.0 & 70 & $\begin{array}{c}\text { Strongly } \\
\text { agreed }\end{array}$ & \multirow{6}{*}{$\begin{array}{c}\text { Vali } \\
\text { d } \\
\text { res } \\
\text { ults }\end{array}$} \\
\hline 67.9 & 42.9 & 42.9 & 120 & Agreed & \\
\hline 82.1 & 14.3 & 14.3 & 40 & Neutral & \\
\hline 92.9 & 10.7 & 10.7 & 30 & Disagree & \\
\hline \multirow[t]{2}{*}{100.0} & 7.1 & 7.1 & 20 & $\begin{array}{c}\text { Strongly } \\
\text { disagreed }\end{array}$ & \\
\hline & 100.0 & 100.0 & 280 & Total & \\
\hline
\end{tabular}




\begin{tabular}{|c|c|c|c|c|c|}
\hline \multicolumn{6}{|c|}{ Table of occurrences of the sub-independent variable VX9 } \\
\hline $\begin{array}{l}\text { Cumulative } \\
\text { percentage }\end{array}$ & $\begin{array}{c}\text { The valid } \\
\text { ratio }\end{array}$ & $\begin{array}{l}\text { The } \\
\text { ratio }\end{array}$ & $\begin{array}{c}\text { Duplicat } \\
\text { es }\end{array}$ & \multicolumn{2}{|c|}{ Categories } \\
\hline 28.6 & 28.6 & 28.6 & 80 & $\begin{array}{c}\text { Strongly } \\
\text { agreed }\end{array}$ & \multirow{5}{*}{$\begin{array}{c}\text { Vali } \\
\text { d } \\
\text { res } \\
\text { ults }\end{array}$} \\
\hline 67.9 & 39.3 & 39.3 & 110 & Agreed & \\
\hline 71.4 & 3.6 & 3.6 & 10 & Neutral & \\
\hline \multirow[t]{2}{*}{100.0} & 28.6 & 28.6 & 80 & Disagree & \\
\hline & 100.0 & 100.0 & 280 & Total & \\
\hline
\end{tabular}

\begin{tabular}{|c|c|c|c|c|c|}
\hline \multicolumn{6}{|c|}{ Table of occurrences of the sub-independent variable VX10 } \\
\hline $\begin{array}{l}\text { Cumulative } \\
\text { percentage }\end{array}$ & $\begin{array}{c}\text { The valid } \\
\text { ratio }\end{array}$ & $\begin{array}{c}\text { The } \\
\text { ratio }\end{array}$ & $\begin{array}{c}\text { Duplicat } \\
\text { es }\end{array}$ & \multicolumn{2}{|c|}{ Categories } \\
\hline 28.6 & 28.6 & 28.6 & 80 & $\begin{array}{c}\text { Strongly } \\
\text { agreed }\end{array}$ & \multirow{6}{*}{\begin{tabular}{|c} 
Vali \\
d \\
res \\
ults
\end{tabular}} \\
\hline 75.0 & 46.4 & 46.4 & 130 & Agreed & \\
\hline 85.7 & 10.7 & 10.7 & 30 & Neutral & \\
\hline 96.4 & 10.7 & 10.7 & 30 & Disagree & \\
\hline \multirow[t]{2}{*}{100.0} & 3.6 & 3.6 & 10 & $\begin{array}{c}\text { Strongly } \\
\text { disagreed }\end{array}$ & \\
\hline & 100.0 & 100.0 & 280 & Total & \\
\hline
\end{tabular}


Summary of general occurrences of the dependent variable Descriptive Statistics VY's

\begin{tabular}{|c|c|c|c|c|c|c|c|c|c|c|c|}
\hline \multicolumn{12}{|c|}{$\begin{array}{l}\text { Summary of general occurrences of the dependent variable Descriptive } \\
\text { Statistics VY's }\end{array}$} \\
\hline $\begin{array}{l}\text { VY } \\
10\end{array}$ & $\begin{array}{c}\text { VY } \\
9\end{array}$ & $\begin{array}{l}\mathbf{V Y} \\
\mathbf{8}\end{array}$ & $\begin{array}{c}\text { VY } \\
7\end{array}$ & $\begin{array}{c}\text { VY } \\
6\end{array}$ & $\begin{array}{l}\text { VY } \\
5\end{array}$ & $\begin{array}{c}\text { VY } \\
4\end{array}$ & $\begin{array}{l}\text { VY } \\
3\end{array}$ & $\begin{array}{c}\mathbf{V Y} \\
\mathbf{2}\end{array}$ & $\begin{array}{c}\text { VY } \\
1\end{array}$ & \multicolumn{2}{|c|}{ the details } \\
\hline 280 & 280 & 280 & 280 & 280 & 280 & 280 & 280 & 280 & 280 & $\begin{array}{l}\text { Valid } \\
\text { result }\end{array}$ & \multirow{2}{*}{$\begin{array}{c}\text { th } \\
\text { e } \\
\text { nu } \\
\text { m } \\
\text { be } \\
\text { r }\end{array}$} \\
\hline 0 & 0 & 0 & 0 & 0 & 0 & 0 & 0 & 0 & 0 & $\begin{array}{r}\text { Invalic } \\
\text { result }\end{array}$ & \\
\hline $\begin{array}{c}2.1 \\
4\end{array}$ & $\begin{array}{c}2.4 \\
6\end{array}$ & $\begin{array}{c}2.0 \\
7\end{array}$ & $\begin{array}{c}2.5 \\
7\end{array}$ & $\begin{array}{c}2.1 \\
8\end{array}$ & $\begin{array}{c}2.5 \\
4\end{array}$ & $\begin{array}{c}2.2 \\
9\end{array}$ & $\begin{array}{c}2.4 \\
6\end{array}$ & $\begin{array}{c}1.9 \\
3\end{array}$ & $\begin{array}{c}2.0 \\
0\end{array}$ & \multicolumn{2}{|c|}{$\begin{array}{c}\text { Arithmetic } \\
\text { mean }\end{array}$} \\
\hline $\begin{array}{l}1.1 \\
45\end{array}$ & $\begin{array}{l}1.1 \\
05\end{array}$ & $\begin{array}{c}.97 \\
9\end{array}$ & $\begin{array}{c}.99 \\
7\end{array}$ & $\begin{array}{l}1.1 \\
24\end{array}$ & $\begin{array}{l}1.3 \\
19\end{array}$ & $\begin{array}{l}1.0 \\
49\end{array}$ & $\begin{array}{l}1.1 \\
70\end{array}$ & $\begin{array}{c}.94 \\
0\end{array}$ & $\begin{array}{l}1.0 \\
54\end{array}$ & \multicolumn{2}{|c|}{$\begin{array}{l}\text { standard } \\
\text { deviation }\end{array}$} \\
\hline $\begin{array}{c}.81 \\
6\end{array}$ & $\begin{array}{l}-.1 \\
69\end{array}$ & $\begin{array}{c}.61 \\
5\end{array}$ & $\begin{array}{c}.27 \\
1\end{array}$ & $\begin{array}{c}.63 \\
4\end{array}$ & $\begin{array}{c}.54 \\
3\end{array}$ & $\begin{array}{c}.20 \\
3\end{array}$ & $\begin{array}{c}.76 \\
5\end{array}$ & $\begin{array}{l}1.0 \\
14\end{array}$ & $\begin{array}{c}.81 \\
7\end{array}$ & \multicolumn{2}{|c|}{ skewness } \\
\hline $\begin{array}{c}.44 \\
1\end{array}$ & $\begin{array}{c}.44 \\
1\end{array}$ & $\begin{array}{c}.44 \\
1\end{array}$ & $\begin{array}{c}.44 \\
1\end{array}$ & $\begin{array}{c}.44 \\
1\end{array}$ & $\begin{array}{c}.44 \\
1\end{array}$ & $\begin{array}{c}.44 \\
1\end{array}$ & $\begin{array}{c}.44 \\
1\end{array}$ & $\begin{array}{c}.44 \\
1\end{array}$ & $\begin{array}{c}.44 \\
1\end{array}$ & \multicolumn{2}{|c|}{$\begin{array}{c}\text { Error } \\
\text { criterion for } \\
\text { torsion } \\
\text { modifier }\end{array}$} \\
\hline
\end{tabular}

Frequency tables for sub-paragraphs of the dependent variable Frequency Table of VY's

\begin{tabular}{|c|c|c|c|c|c|}
\hline \multicolumn{6}{|c|}{ Table of occurrences of the sub-dependent variable VY1 } \\
\hline $\begin{array}{l}\text { Cumulative } \\
\text { percentage }\end{array}$ & $\begin{array}{c}\text { The valid } \\
\text { ratio }\end{array}$ & $\begin{array}{l}\text { The } \\
\text { ratio }\end{array}$ & $\begin{array}{c}\text { Duplicat } \\
\text { es }\end{array}$ & \multicolumn{2}{|c|}{ Categories } \\
\hline 39.3 & 39.3 & 39.3 & 110 & $\begin{array}{c}\text { Strongly } \\
\text { agreed }\end{array}$ & \multirow{5}{*}{$\begin{array}{c}\text { Vali } \\
\text { d } \\
\text { res } \\
\text { ults }\end{array}$} \\
\hline 75.0 & 35.7 & 35.7 & 100 & Agreed & \\
\hline 85.7 & 10.7 & 10.7 & 30 & Neutral & \\
\hline \multirow[t]{2}{*}{100.0} & 14.3 & 14.3 & 40 & Disagree & \\
\hline & 100.0 & 100.0 & 280 & Total & \\
\hline
\end{tabular}




\begin{tabular}{|c|c|c|c|c|c|}
\hline \multicolumn{6}{|c|}{ Table of occurrences of the sub-dependent variable VY2 } \\
\hline $\begin{array}{l}\text { Cumulative } \\
\text { percentage }\end{array}$ & $\begin{array}{c}\text { The valid } \\
\text { ratio }\end{array}$ & $\begin{array}{l}\text { The } \\
\text { ratio }\end{array}$ & $\begin{array}{c}\text { Duplicat } \\
\text { es }\end{array}$ & \multicolumn{2}{|c|}{ Categories } \\
\hline 35.7 & 35.7 & 35.7 & 100 & $\begin{array}{c}\text { Strongly } \\
\text { agreed }\end{array}$ & \multirow{5}{*}{$\begin{array}{c}\text { Vali } \\
\text { d } \\
\text { res } \\
\text { ults }\end{array}$} \\
\hline 82.1 & 46.4 & 46.4 & 130 & Agreed & \\
\hline 89.3 & 7.1 & 7.1 & 20 & Neutral & \\
\hline \multirow[t]{2}{*}{100.0} & 10.7 & 10.7 & 30 & Disagree & \\
\hline & 100.0 & 100.0 & 280 & Total & \\
\hline
\end{tabular}

\begin{tabular}{|c|c|c|c|c|c|}
\hline \multicolumn{6}{|c|}{ Table of occurrences of the sub-dependent variable VY3 } \\
\hline $\begin{array}{l}\text { Cumulative } \\
\text { percentage }\end{array}$ & $\begin{array}{l}\text { The valid } \\
\text { ratio }\end{array}$ & $\begin{array}{l}\text { The } \\
\text { ratio }\end{array}$ & $\begin{array}{l}\text { Duplicat } \\
\text { es }\end{array}$ & \multicolumn{2}{|c|}{ Categories } \\
\hline 17.9 & 17.9 & 17.9 & 50 & $\begin{array}{c}\text { Strongly } \\
\text { agreed }\end{array}$ & \multirow{6}{*}{$\begin{array}{c}\text { Vali } \\
\text { d } \\
\text { res } \\
\text { ults }\end{array}$} \\
\hline 64.3 & 46.4 & 46.4 & 130 & Agreed & \\
\hline 78.6 & 14.3 & 14.3 & 40 & Neutral & \\
\hline 92.9 & 14.3 & 14.3 & 40 & Disagree & \\
\hline \multirow[t]{2}{*}{100.0} & 7.1 & 7.1 & 20 & $\begin{array}{c}\text { Strongly } \\
\text { disagreed }\end{array}$ & \\
\hline & 100.0 & 100.0 & 280 & Total & \\
\hline
\end{tabular}

\begin{tabular}{|c|c|c|c|c|c|}
\hline \multicolumn{6}{|c|}{ Table of occurrences of the sub-dependent variable VY4 } \\
\hline $\begin{array}{l}\text { Cumulative } \\
\text { percentage }\end{array}$ & $\begin{array}{c}\text { The valid } \\
\text { ratio }\end{array}$ & $\begin{array}{c}\text { The } \\
\text { ratio }\end{array}$ & $\begin{array}{c}\text { Duplicat } \\
\text { es }\end{array}$ & \multicolumn{2}{|c|}{ Categories } \\
\hline 28.6 & 28.6 & 28.6 & 80 & $\begin{array}{c}\text { Strongly } \\
\text { agreed }\end{array}$ & \multirow{5}{*}{$\begin{array}{c}\text { Vali } \\
\text { d } \\
\text { res } \\
\text { ults }\end{array}$} \\
\hline 57.1 & 28.6 & 28.6 & 80 & Agreed & \\
\hline 85.7 & 28.6 & 28.6 & 80 & Neutral & \\
\hline \multirow[t]{2}{*}{100.0} & 14.3 & 14.3 & 40 & Disagree & \\
\hline & 100.0 & 100.0 & 280 & Total & \\
\hline
\end{tabular}




\begin{tabular}{|c|c|c|c|c|c|}
\hline \multicolumn{6}{|c|}{ Table of occurrences of the sub-dependent variable VY5 } \\
\hline $\begin{array}{l}\text { Cumulative } \\
\text { percentage }\end{array}$ & $\begin{array}{c}\text { The valid } \\
\text { ratio }\end{array}$ & $\begin{array}{l}\text { The } \\
\text { ratio }\end{array}$ & $\begin{array}{c}\text { Duplicat } \\
\text { es }\end{array}$ & \multicolumn{2}{|c|}{ Categories } \\
\hline 25.0 & 25.0 & 25.0 & 70 & $\begin{array}{c}\text { Strongly } \\
\text { agreed }\end{array}$ & \multirow{6}{*}{$\begin{array}{c}\text { Vali } \\
\text { d } \\
\text { res } \\
\text { ults }\end{array}$} \\
\hline 57.1 & 32.1 & 32.1 & 90 & Agreed & \\
\hline 75.0 & 17.9 & 17.9 & 50 & Neutral & \\
\hline 89.3 & 14.3 & 14.3 & 40 & Disagree & \\
\hline \multirow[t]{2}{*}{100.0} & 10.7 & 10.7 & 30 & $\begin{array}{c}\text { Strongly } \\
\text { disagreed }\end{array}$ & \\
\hline & 100.0 & 100.0 & 280 & Total & \\
\hline
\end{tabular}

\begin{tabular}{|c|c|c|c|c|c|}
\hline \multicolumn{6}{|c|}{ Table of occurrences of the sub-dependent variable VY6 } \\
\hline $\begin{array}{l}\text { Cumulative } \\
\text { percentage }\end{array}$ & $\begin{array}{l}\text { The valid } \\
\text { ratio }\end{array}$ & $\begin{array}{l}\text { The } \\
\text { ratio }\end{array}$ & $\begin{array}{c}\text { Duplicat } \\
\text { es }\end{array}$ & \multicolumn{2}{|c|}{ Categories } \\
\hline 35.7 & 35.7 & 35.7 & 100 & $\begin{array}{c}\text { Strongly } \\
\text { agreed }\end{array}$ & \multirow{6}{*}{$\begin{array}{c}\text { Vali } \\
\text { d } \\
\text { res } \\
\text { ults }\end{array}$} \\
\hline 60.7 & 25.0 & 25.0 & 70 & Agreed & \\
\hline 89.3 & 28.6 & 28.6 & 80 & Neutral & \\
\hline 96.4 & 7.1 & 7.1 & 20 & Disagree & \\
\hline \multirow[t]{2}{*}{100.0} & 3.6 & 3.6 & 10 & $\begin{array}{c}\text { Strongly } \\
\text { disagreed }\end{array}$ & \\
\hline & 100.0 & 100.0 & 280 & Total & \\
\hline
\end{tabular}

\begin{tabular}{|c|c|c|c|c|c|}
\hline \multicolumn{6}{|c|}{ Table of occurrences of the sub-dependent variable VY7 } \\
\hline $\begin{array}{c}\text { Cumulative } \\
\text { percentage }\end{array}$ & $\begin{array}{c}\text { The valid } \\
\text { ratio }\end{array}$ & $\begin{array}{c}\text { The } \\
\text { ratio }\end{array}$ & $\begin{array}{c}\text { Duplicat } \\
\text { es }\end{array}$ & \multicolumn{2}{|c|}{ Categories } \\
\hline 10.7 & 10.7 & 10.7 & 30 & $\begin{array}{c}\text { Strongly } \\
\text { agreed }\end{array}$ \\
\hline
\end{tabular}




\begin{tabular}{|c|c|c|c|c|c|}
\hline 57.1 & 46.4 & 46.4 & 130 & Agreed & \multirow{4}{*}{$\begin{array}{c}\text { Vali } \\
\text { d } \\
\text { res } \\
\text { ults }\end{array}$} \\
\hline 75.0 & 17.9 & 17.9 & 50 & Neutral & \\
\hline 100.0 & 25.0 & 25.0 & 70 & Disagree & \\
\hline & 100.0 & 100.0 & 280 & Total & \\
\hline
\end{tabular}

\begin{tabular}{|c|c|c|c|c|c|}
\hline \multicolumn{6}{|c|}{ Table of occurrences of the sub-dependent variable VY8 } \\
\hline $\begin{array}{l}\text { Cumulative } \\
\text { percentage }\end{array}$ & $\begin{array}{l}\text { The valid } \\
\text { ratio }\end{array}$ & $\begin{array}{l}\text { The } \\
\text { ratio }\end{array}$ & $\begin{array}{c}\text { Duplicat } \\
\text { es }\end{array}$ & \multicolumn{2}{|c|}{ Categories } \\
\hline 32.1 & 32.1 & 32.1 & 90 & $\begin{array}{c}\text { Strongly } \\
\text { agreed }\end{array}$ & \multirow{5}{*}{$\begin{array}{c}\text { Vali } \\
\text { d } \\
\text { res } \\
\text { ults }\end{array}$} \\
\hline 71.4 & 39.3 & 39.3 & 110 & Agreed & \\
\hline 89.3 & 17.9 & 17.9 & 50 & Neutral & \\
\hline \multirow[t]{2}{*}{100.0} & 10.7 & 10.7 & 30 & Disagree & \\
\hline & 100.0 & 100.0 & 280 & Total & \\
\hline
\end{tabular}

\begin{tabular}{|c|c|c|c|c|c|}
\hline \multicolumn{6}{|c|}{ Table of occurrences of the sub-dependent variable VY9 } \\
\hline $\begin{array}{l}\text { Cumulative } \\
\text { percentage }\end{array}$ & $\begin{array}{c}\text { The valid } \\
\text { ratio }\end{array}$ & $\begin{array}{l}\text { The } \\
\text { ratio }\end{array}$ & $\begin{array}{c}\text { Duplicat } \\
\text { es }\end{array}$ & \multicolumn{2}{|c|}{ Categories } \\
\hline 28.6 & 28.6 & 28.6 & 80 & $\begin{array}{c}\text { Strongly } \\
\text { agreed }\end{array}$ & \multirow{5}{*}{$\begin{array}{c}\text { Vali } \\
\text { d } \\
\text { res } \\
\text { ults }\end{array}$} \\
\hline 42.9 & 14.3 & 14.3 & 40 & Agreed & \\
\hline 82.1 & 39.3 & 39.3 & 110 & Neutral & \\
\hline \multirow[t]{2}{*}{100.0} & 17.9 & 17.9 & 50 & Disagree & \\
\hline & 100.0 & 100.0 & 280 & Total & \\
\hline
\end{tabular}

\begin{tabular}{|c|c|c|c|c|c|}
\hline \multicolumn{6}{|c|}{ Table of occurrences of the sub-dependent variable VY10 } \\
\hline $\begin{array}{c}\text { Cumulative } \\
\text { percentage }\end{array}$ & $\begin{array}{c}\text { The valid } \\
\text { ratio }\end{array}$ & $\begin{array}{c}\text { The } \\
\text { ratio }\end{array}$ & $\begin{array}{c}\text { Duplicat } \\
\text { es }\end{array}$ & \multicolumn{2}{|c|}{ Categories } \\
\hline 35.7 & 35.7 & 35.7 & 100 & $\begin{array}{c}\text { Strongly } \\
\text { agreed }\end{array}$ \\
\hline
\end{tabular}




\begin{tabular}{|c|c|c|c|c|c|}
\hline 67.9 & 32.1 & 32.1 & 90 & Agreed & \multirow{5}{*}{$\begin{array}{c}\text { Vali } \\
\text { d } \\
\text { res } \\
\text { ults }\end{array}$} \\
\hline 85.7 & 17.9 & 17.9 & 50 & Neutral & \\
\hline 96.4 & 10.7 & 10.7 & 30 & Disagree & \\
\hline \multirow[t]{2}{*}{100.0} & 3.6 & 3.6 & 10 & $\begin{array}{l}\text { Strongly } \\
\text { disagreed }\end{array}$ & \\
\hline & 100.0 & 100.0 & 280 & Total & \\
\hline
\end{tabular}

Correlations coefficient between the independent variables VX and the Correlations VY

\begin{tabular}{|c|c|c|c|}
\hline \multicolumn{4}{|c|}{ Correlation coefficients Correlations } \\
\hline $\begin{array}{c}\text { Dependent } \\
\text { variable VY }\end{array}$ & $\begin{array}{l}\text { Independent } \\
\text { variable VX }\end{array}$ & \multicolumn{2}{|c|}{ the details } \\
\hline .227 & 10 & $\begin{array}{c}\text { Pearson } \\
\text { Correlation } \\
\text { Coefficient }\end{array}$ & \multirow{3}{*}{$\begin{array}{l}\text { Independent } \\
\text { variable VX }\end{array}$} \\
\hline .246 & & $\begin{array}{c}\text { The importance of } \\
\text { the correlation } \\
\text { between the two } \\
\text { variables }\end{array}$ & \\
\hline 28 & 280 & the number & \\
\hline \multirow[t]{2}{*}{1} & .227 & $\begin{array}{c}\text { Pearson } \\
\text { Correlation } \\
\text { Coefficient }\end{array}$ & \multirow{3}{*}{$\begin{array}{c}\text { Dependent } \\
\text { variable VY }\end{array}$} \\
\hline & .246 & $\begin{array}{c}\text { The importance of } \\
\text { the correlation } \\
\text { between the two } \\
\text { variables }\end{array}$ & \\
\hline 28 & 280 & the number & \\
\hline
\end{tabular}


Simple linear regression between the independent variables VX and the dependent VY Linear Regression

\begin{tabular}{|c|l|c|c|}
\hline \multicolumn{4}{|c|}{ Variables Entered/ Removed Table type method a } \\
\hline Way & Eliminate variables & $\begin{array}{c}\text { Input } \\
\text { variables }\end{array}$ & $\begin{array}{c}\text { Sam } \\
\text { ple }\end{array}$ \\
\hline The entry &. & VYb & 1 \\
\hline
\end{tabular}

a. Independent variable VX

b. All required parameters have been entered

\begin{tabular}{|c|c|c|c|c|}
\hline \multicolumn{4}{|c|}{ Table of Linear Correlation Summary of Models Model Summary } \\
\hline $\begin{array}{c}\text { Error estimation } \\
\text { criterion }\end{array}$ & $\begin{array}{c}\text { Adjusted } \\
\text { coefficient of } \\
\text { determinatio } \\
\mathbf{n}\end{array}$ & $\begin{array}{c}\text { The } \\
\text { coefficient } \\
\text { of } \\
\text { determinat } \\
\text { ion }\end{array}$ & $\begin{array}{c}\text { Correlati } \\
\text { on } \\
\text { coefficie } \\
\text { nt }\end{array}$ & Sam \\
ple \\
\hline .752 & .015 & .051 & $.227 \mathrm{a}$ & 1 \\
\hline
\end{tabular}

